\title{
Patterns of production and sedimentation in the boreal and polar Northeast Atlantic
}

\author{
PAUL WASSMANN. ROLF PEINERT and VICTOR SMETACEK
}

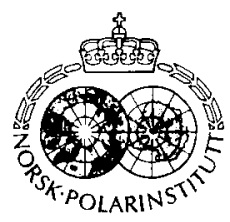

\begin{abstract}
Wassmann, P., Peinert, R. \& Smetacek, V. 1991: Patterns of production and sedimentation in the boreal and polar Northeast Atlantic. Pp. 209-228 in Sakshaug, E., Hopkins, C. C. E. \& Oritsland, N. A. (eds.): Proceedings of the Pro Mare Symposium on Polar Marine Ecology, Trondheim, 12-16 May 1990. Polar Research 10(I).
\end{abstract}

Pelagic systems are potentially capable of retaining and recycling all autochthonous organic material, although some losses due to sinking particles inevitably occur. Relating processes in the surface layers quantitatively to vertical particle flux is difficult because only a small percentage of the total production is lost annually via sinking in the open ocean. Further, only a few types of particles contribute to this flux and only a small proportion of these may actually reach greater depths.

Measurements of vertical flux with sediment traps revealed seasonal and regional patterns also within the northwestern Atlantic and indicate imbalances between particle formation and degradation. The classical pattern of spring bloom sedimentation followed by reduced loss rates has been found in shelf and shallow water regions such as the Norwegian Coastal Current and fjords and is also encountered in the Barents Sea. In the Norwegian Sea, however, the seasonal pattern appears different as the seasonal maximum has been observed duting late summer/autumn.

The physical environment determines nutrient availability and hence the particles potentially available for sedimentation. The relationship between phyto- and zooplankton governs vertical flux seasonality, and zooplankters with different life cycles and feeding strategies further modify the principle patterns. Herbivores with life-cycle strategies involving overwintering of large biomass and predictable seasonal appearance (copepods, cuphausiids) will have a different impact than opportunistic organisms with very low overwintering biomass, for example salps and pteropods. The latter exhibit much greater interannual biomass variation and may thus contribute to interannual variability of the vertical flux. Shelf systems of similar latitude are generally comparable with respect to their flux patterns and also share similarities with marginal ice zones. Open ocean systems as the Norwegian Sea, however, cxhibit different patterns which are similar to the subarctic Pacific.

Paul Wassmann. Norwegian College of Fishery Science, University of Tromsø, P.O. Box 3083 Guleng. N-900I Tromsø. Norway; Rolf Peinen. Institut für Meereskunde, Düsternbrookerweg 20, D-2300 Kiel 1. Federal Republic of Germuny; Victor Smetacek. Alfred-Wegener-Institut für Polar- und Meeresforschung. Am Handelshafen 12, D-2850 Bremerhaven, Germany.

\section{Introduction}

Sediment trap deployments conducted in the seventies in localities as disparate as the deep Sargasso Sea (Deuser \& Ross 1980), the Baltic Sea (Smetacek et al. 1978) and the shallow waters of Kiel Bight (Smetacek 1980a) revealed a strikingly common feature. The annual sedimentation pattern was dominated by a strong pulse following the spring bloom with lower rates during the rest of the year. An additional autumn maximum in Kiel Bight could be related to the autumn blooms which occur there regularly but not in the other areas. This spring pulse was accepted as the paradigm case for waters experiencing a spring bloom.

The combination of insolation, shallowing of the mixed layer due to fresh-water run-off, melting ice and/or solar warming and high concentrations of winter-accumulated nutrients in the euphotic zone provide the basis for the spring phytoplankton bloom (Fig. 1). It starts normally in March in the boreal zone and a second bloom might take place in August/September when nutrients are mixed upwards from deeper layers. The spring phytoplankton bloom starts in April or later in the Arctic and since light reaches limiting values by September, only one bloom occurs. The low herbivore biomass at the end of the winter period and the resulting low grazing pressure results in a slow response of zooplankton to increasing food supply, particularly in the Arctic (Heinrich 1962; Smetacek et al. 1984; Peinert et al. 1989; Tande 1991 this volume). As a result, extensive sedimentation of ungrazed phytoplankton and phytodetritus takes place during the senescent stage of the spring bloom.

Despite the pulsed nature of vertical flux, 


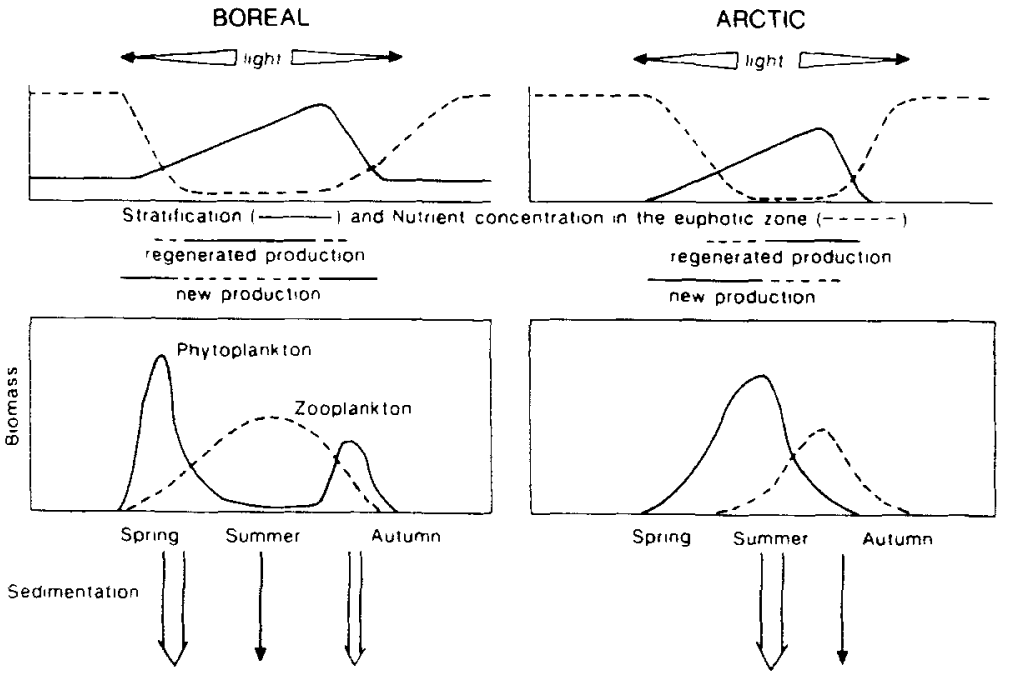

Fig. 1. Conceptual diagram of seasonal changes in physical factors, phytoplankton stocks, new and regenerated production and sedimentation for boreal and Arctic areas. annual integrations of sedimentation acquired from early trap deployments yielded a linear-log relationship with annual primary production in the overlying water column (Suess 1980). Recently, Wassmann (1990) has shown that such a simple model can be applied to boreal coastal waters of the North Atlantic.

In the early eighties, it was widely accepted that the sedimentation rate in a given region could be ascertained from knowledge of primary production: the higher the production, the greater the proportion settling out (Berger et al. 1989). The concept of primary production, however. underwent a differentiation since we now distinguish "new" from "regenerated" production (Eppley \& Peterson 1979) and the "new" production sets the upper limit to particle flux out of a given water column (Platt et al. 1988). It seemed reasonable to assume that major flux pulses would follow periods dominated by new production, i.e. the spring bloom (Fig. 1). Attention next focused on the processes that control the vertical flux of particles from the mixed layer (Cadée 1985; Alldredge \& Silver 1988: Lampitt et al. 1990).

During the eighties, sediment traps were deployed in a variety of localities. Results from these studies indicate that annual patterns in different regions can deviate substantially from the spring maximum paradigm that emerged during the seventies. Considerable interannual variation in rates and even patterns recorded from the same region have also come to light (Deuser 1988). The new data do not disprove the earlier paradigm. they merely demonstrate its restricted applicability. Indeed, implications arising from an assessment of the recent data on vertical flux are already overturning another, older paradigm: the implicitly accepted patterns of the annual cycles of phytoplankton and zooplankton as exemplified by the curves of Heinrich (1962) which represent different regions of the world ocean. We now know that these might well be basic types dictated by the physical environment, but in fact the variability is much greater than previously envisioned.

Sediment traps are powerful tools in furthering our understanding of the dynamics of pelagic systems (GOFS 1989). They not only collect the material settling out of the upper layer but also demonstrate which types of suspended particles do not sink out, or do so only rarely. Interregional and inter-seasonal comparisons (Honjo 1990) provide a very useful framework to interpret, in ecologically meaningful terms, the perplexing data now being derived from sediment trap deployments.

Complications of primary production rates in the world ocean (e.g. Koblentz-Mishke et al. 1970) as well as satellite-derived phytoplankton pigment distribution in the North Atlantic (Brewer et al. 1986) indicate that the Northeast Atlantic is highly productive. This area is characterised by vast shelf areas including the North Sea and the Barents Sea that are open to exchange with ocean basins (Figs. 2 and 3). In contrast to the circular flow of the North Pacific gyre, warm 
Fig. 2. Topography of the boreal and polar Northeast Atlantic (200 and $1000 \mathrm{~m}$ contours) and sediment trap mooring sites referred to in the text. $\mathrm{LI}=$ Lindåspollene; $\mathbf{F A}=$ Fanafjorden; VP = Vøring Plateau; NCC = Norwegian Coastal Current; NA-1 = Aegir Ridge-1; NB-1 = Jan Mayen; LB 1 Lofoten Basin; BA = Balsfjorden; BI-1 = Bjørnøya; BS = Barents Sea sampling area (thin broken line); FS-1 = Fram Strait; GB-2 = Greenland Basin. Also shown is the sea ice cover: average minimum and maximum in May (-.--) and August ( $\longrightarrow$ )

(Redrawn from Wadhams 1986).

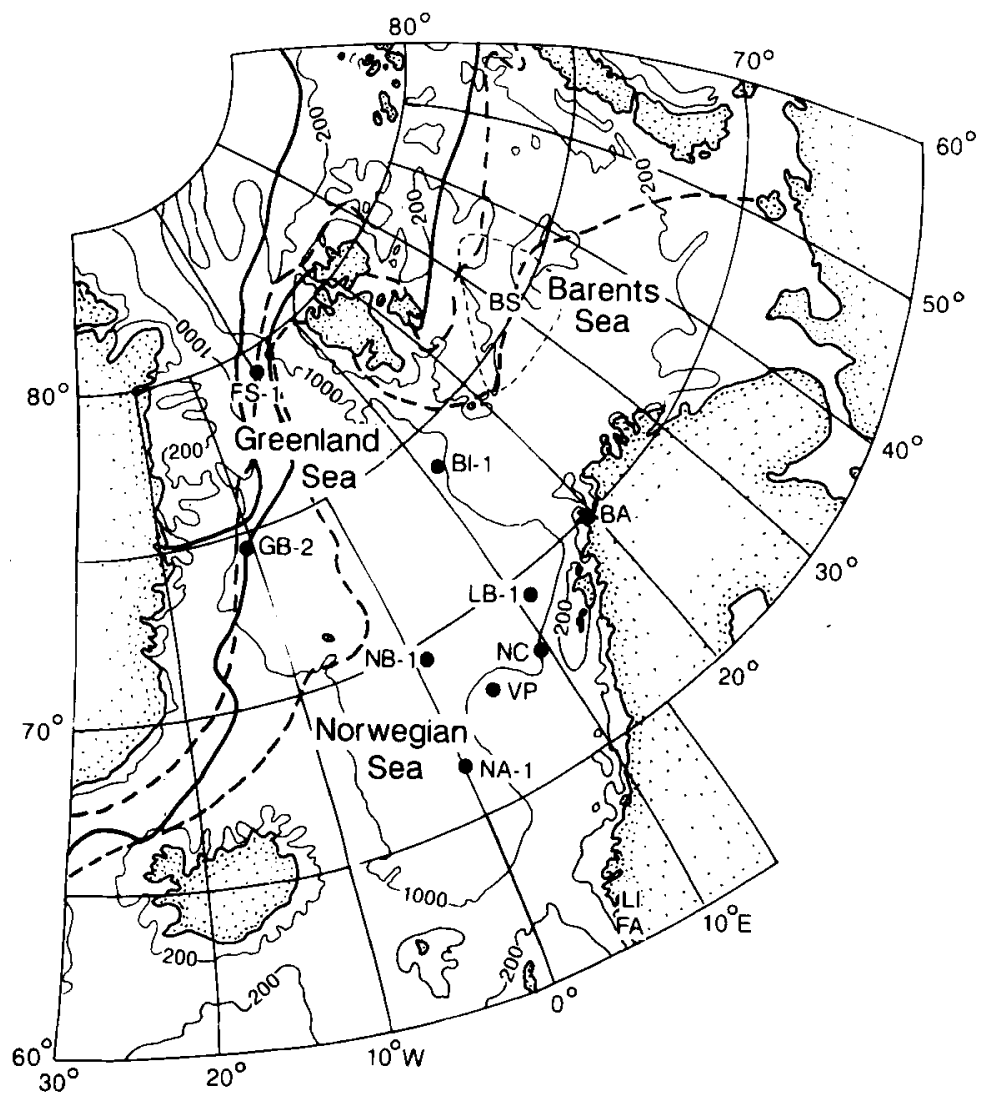

Atlantic Water is transported northward along the eastern side beyond $80^{\circ} \mathrm{N}$, whereas both cold Arctic Surface Water flowing along the western side and deep bottom water are exported southwards into lower latitudes (Fig. 3). While the North Pacific could be characterised as a more closed and circular system, the North Atlantic is an open, asymmetric system with horizontal advection being of great importance for structuring pelagic systems and, hence, also their sedimentation patterns. The depth of winter mixing varies regionally with maxima of several thousands of metres south off Iceland and in the central Norwegian Sea where North Atlantic Deep and Bottom waters are formed. Further, there is a large latitudinal gradient of incident light and the Nordic Seas are characterised by a seasonally variable sea-ice cover in the west, north and northeast (Fig. 2) as well as by extensive fronts between Arctic Water and Atlantic Water (Fig. 3).
The regional pattern of the timing of "biological spring" depicted in Fig. 4 averaged over a 10year period has been compiled by Pavshtiks \& Timokina (1972). The advent of biological spring is triggered by stabilisation of a shallow surface layer which arises earliest in the southern realm, particularly marked along the Norwegian shelf. However, the occurrence of an early spring off the Greenland shelf and across the Barents Sea is related to melting at the ice edge. Further north and in the open Greenland Sea, spring commences as late as July/August. The unstable water column northeast of Iceland is noteworthy. One would expect the timing of spring development to have a major influence on sedimentation patterns. The actual situation, however, is much more complicated.

We here discuss vertical flux data from the boreal and polar regions of the Northeast Atlantic with the aim to identify different factors controlling the vertical flux. 


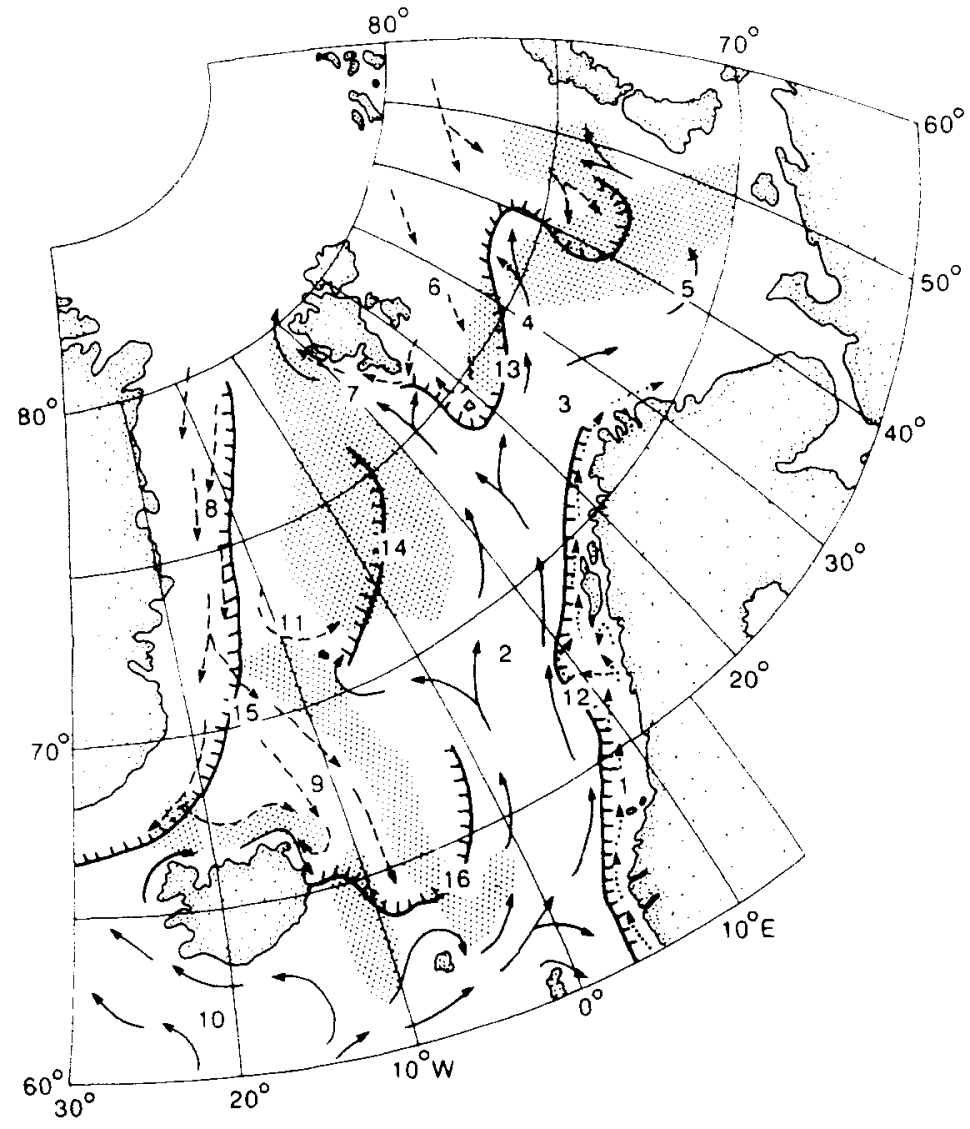

Fig. 3. Surface currents and fronts in the Northeast Atlantic: 1 = Norwegian Coastal Current: 2 = Norwegian Atlantic Current: $3=$ North Cape Current; $4=$ Murmansk Current: $5=$ Kanin Current: $6=$ East Spitsbergen Current: $7=$ West Spitsbergen Current; $8=$ East Greenland Current: $9=$ East Icelandic Current: $10=$ Irminger Current: 11 = Jan Mayen Current. Fronts in the Northeast Atlantic: $12=$ Norwegian Coastal Front; $13=$ Barents Sea Polar Front; $14=$ Polar Ocean Front; 15 = East Grcenland Front and Iceland Gap Front. Shaded areas $=$ mixing of Arctic and Atlantic water.

\section{Case studies}

\section{Northeast Atlantic shelf}

North Sea. - Vertical flux studies were carried out in the Fladen Ground area of the northern North Sea during the springs and early summers of 1976 (FLEX 76) and 1983 (REFLEX 83). Striking differences were recorded between these years. During 1976 a spring bloom comprising small diatoms developed and a strong sedimentation pulse consisting of diatom cells and phytodetritus followed (Davis \& Payne 1984). A substantial portion of organic matter produced by this bloom settled out. In 1983 an unusual, small, colonial prymnesiophyte (Corymbellus aureus) dominated the spring biomass while diatoms attained only secondary importance (Gieskes \& Kraay 1986). No sedimentation pulse was recorded this year (Cadée 1986) and organic material produced by the bloom was apparently retained in the water column.
Norwegian fjords. - The complicated topography of the Norwegian coastal zone, which ranges from 58 to $71^{\circ} \mathrm{N}$, gives rise to a large variety of fjord, trough and shelf systems. Land-locked fjords and open fjords are characterised by different threshold depths at the entrance and different average depths. Open fjords and shelf systems are closely connected and house the same plankton organisms. The ecology of land-locked fjords, however, differs significantly due to restricted water exchange, the exclusion of various types of plankton and the stagnation of bottom water. A "typical" fjord thus does not exist.

Seasonal sedimentation trap deployments in fjords along the Norwegian coast revealed different flux patterns. In the unpolluted land-locked fjord Lindåspollene, for example, major losses were recorded in April and early May with much lower fluxes during the rest of the year (Fig. 5A) (Wassmann 1983; Skjoldal \& Wassmann 1986). In open Fanafjorden in contrast, only little organic 
Fig. 4. Timing of "biological spring", as defined as the beginning of the development of phytoplankton and concentration of $C$. finmarchicus,

Euphausiacea, etc. near the surface (Pavshtiks \& Timokhina 1972) in the Northeast Atlantic. Redrawn from Pavshtiks \& Timokhina (1972) with additional information by U. Stefánsson (pers. comm.) and $\mathrm{K}$. Tande (pers. comm.).

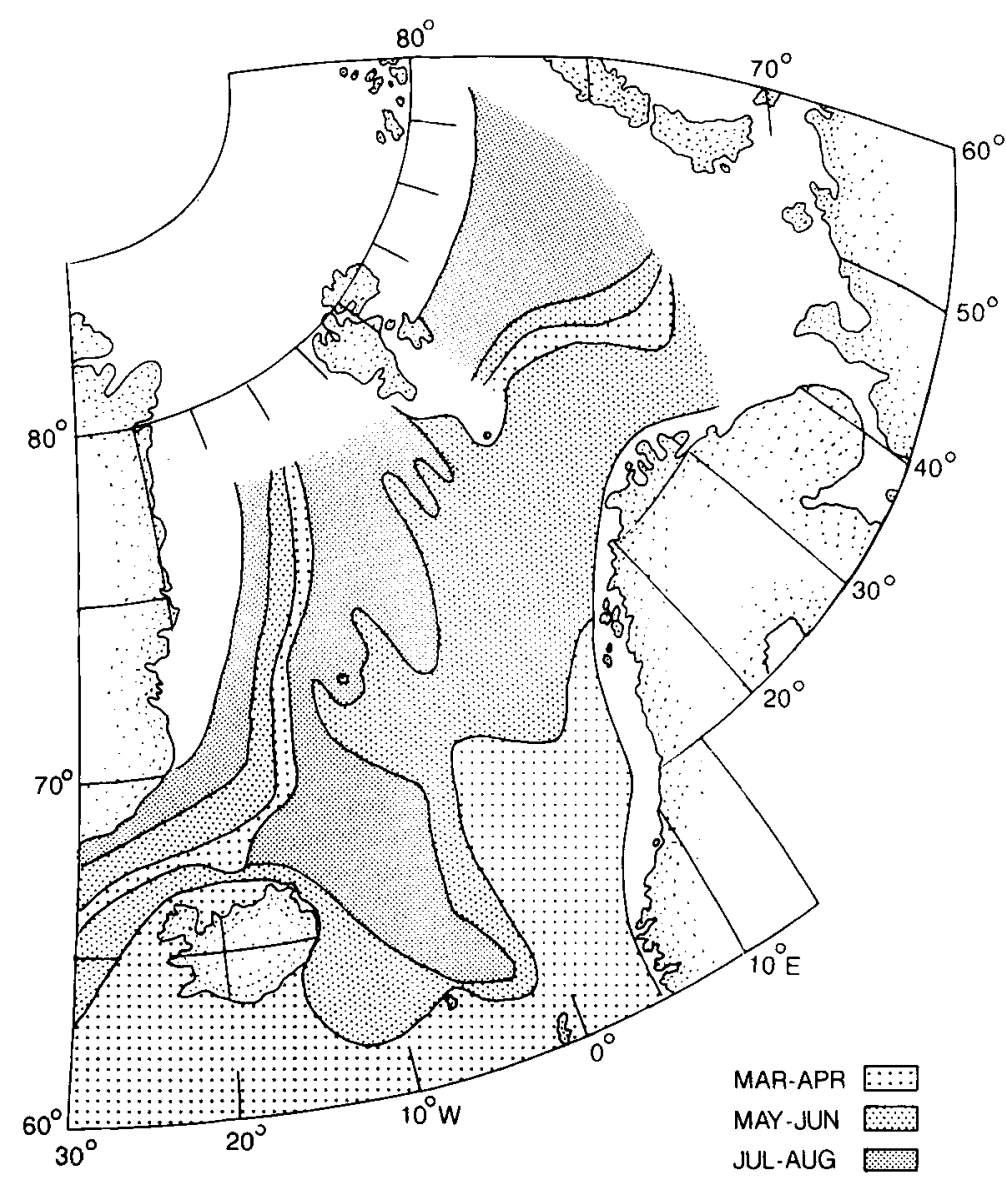

matter from the diatom spring bloom which occurred in April settled out of the mixed layer within the fjord. The bulk of the bloom biomass was probably exported onto the adjacent shelf prior to sedimentation as a result of a wind induced up-welling event. A second phytoplankton bloom, sustained by new nutrients in the newly up-welled water, however, settled out in the fjord itself in May/June. Another, minor increase in sedimentation was measured in autumn when water column stability decreased following strong winds (Fig. 5A). Open fjords could, thus, be characterised as multi-pulse systems (Lindahl 1987; Wassmann 1991), whereas land-locked fjords with threshold depths lower than the seasonal pycnocline would be singlepulse ones.

Also in the open, subarctic Balsfjorden (about $70^{\circ} \mathrm{N}$ ) a seasonality of sedimentation is evident from late winter to early summer (Lutter et al.
1989) (Fig. 5B). The spring maximum following the phytoplankton bloom, however, was much less pronounced compared to Fanafjorden. At greater depth seasonal variation was also less significant. This possibly reflects a spring bloom which starts in weakly-stratified waters (Eilertsen et al. 1981) and, at the same time, is influenced by the grazing by over-wintering herbivorous zooplankters (Hopkins et al. 1985).

The Norwegian shelf. - The few measurements available from the Norwegian shelf (Fig. 5B) indicate a spring maximum of vertical flux and low values during summer, i.e. a pattern comparable to Balsfjorden and the Barents Sea. Spring trap collections from 1983 (Peinert 1986b) contained relatively little intact phytoplankton, indicating that no major phytoplankton sedimentation pulse had been encountered. Summer sedimentation rates were lower, less variable and comprised 

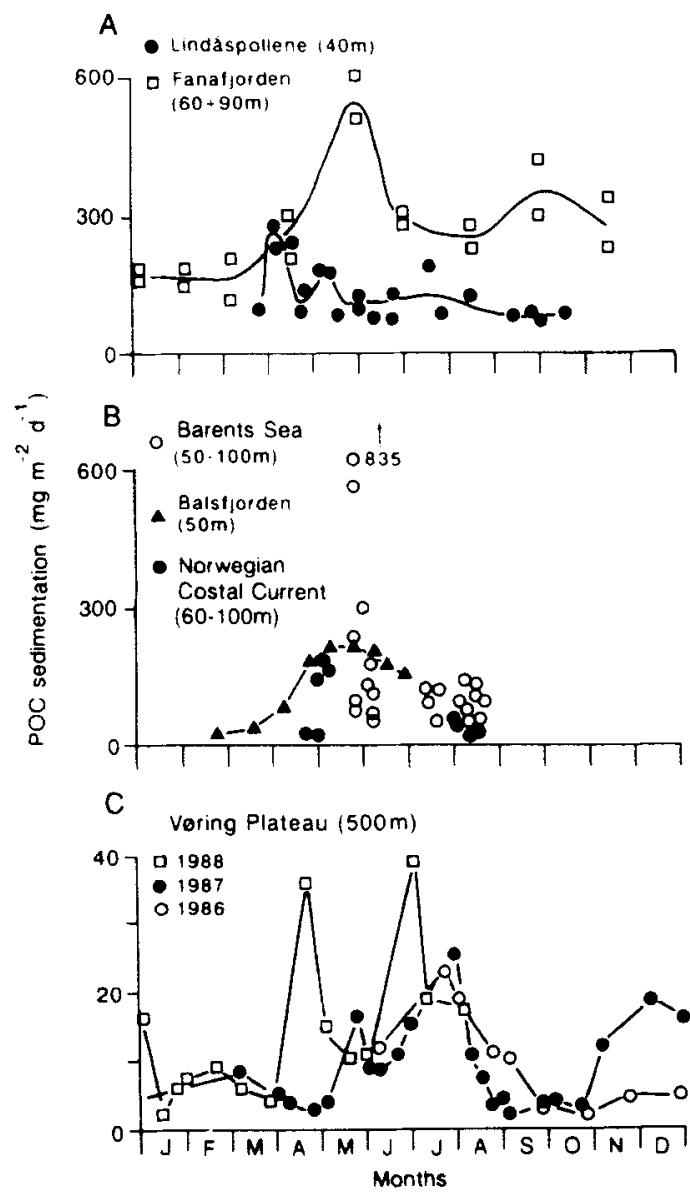

Fig. 5. Sedimentation rates of particulate organic carbon $(\mathrm{mg}$ $\mathrm{C} \mathrm{m}^{-2} \mathrm{~d}^{-1}$ ) in land-locked fjords. open fjords. the Norwegian Coastal Current, the Barents Sea and the Voring Plateau. Data replotted from Wassmann (1983, 1984. 1989). Peinert (1986b). Skjoldal \& Wassmann (1986). Lutter et al. (1989). Bathmann et al. (1990a) and Wassmann et al. (1990).

much less freshly produced matter of phytoplankton origin. The bulk of the trap collections during this season consisted of krill faeces. sometimes loaded with tintinnid loricae.

The horizontal spring phytoplankton distribution in this region is very patchy and coupled to the complex hydrography of the Norwegian Coastal Current (Braarud et al. 1958; Sætre \& Mork 1981). Frontal processes between the Norwegian Atlantic Current and Norwegian Coastal Current. topographically induced gyres on the shelf (Sundby 1984), as well as lateral injections of low salinity water from fjords provide variable conditions for phytoplankton growth. Differences in water column stability, up/ down-welling, nutrient availability at the onset of the growth season and nutrient replenishment by entrainment influence the immediate growth environment. Differences in the initial phytoplankton seeding populations and advection of grazers of different type may modify conditions and hence further contribute to space/time-differences in the spring bloom.

Vertical fluxes, accordingly, must be expected to exhibit an even greater variability in space/ time during spring as highly non-linear factors influence the direct sedimentation of phytoplankton (nutrient exhaustion triggering mass sedimentation, differing settling behavior of phytoplankters). During spring, maximum vertical flux values may well exceed those depicted in Fig. SB (Peinert 1986a), but it may not be easy to document such events as they would be shortterm and spatially restricted. In general, however, a spring sedimentation pulse of freshly produced autotrophic biomass, based on and limited by winter nutrients can be expected regularly on the Norwegian shelf. The shelf, because it is shallow, is not a favorable site for the overwintering of large populations of herbivores. Thus, it has to be colonised by annually dominant grazers during each spring. The resultant time lag between spring phytoplankton growth and the onset of intense grazing pressure (mainly by copepods) primarily controls spring sedimentation rates.

Barents Sea. - The amount and seasonality of sedimentation in the Barents Sea is comparable to those of coastal areas of the boreal zone (Fig. $5 \mathrm{~B}$ ). Highest sedimentation rates of up to $1 \mathrm{~g} \mathrm{C}$ $\mathrm{m}^{-2} \mathrm{~d}^{-1}$ were recorded during a dense Phaeocystis pouchetii bloom in areas dominated by Atlantic Water during May/June (Wassmann et al. 1990). The average sedimentation rate below the euphotic zone $(50 \mathrm{~m})$ during spring was about $300 \mathrm{mg} \mathrm{C} \mathrm{m}^{-2} \mathrm{~d}^{-1}$ (P. Wassmann unpubl. data) with significant variation in different areas of the Barents Sea. During summer, sedimentation rates were much lower and averaged $80 \mathrm{mg} \mathrm{C} \mathrm{m}^{-2} \mathrm{~d}^{-1}$ below the euphotic zone (Wassmann 1989).

The patterns of phytoplankton production and sedimentation in the Barents Sea are strongly influenced by the seasonal and interannual dynamics of sea ice (Rey \& Loeng 1985). While the southwestern part is always ice-free, the central, eastern and southeastern areas are covered by sea ice during spring (Fig. 2). The mar- 


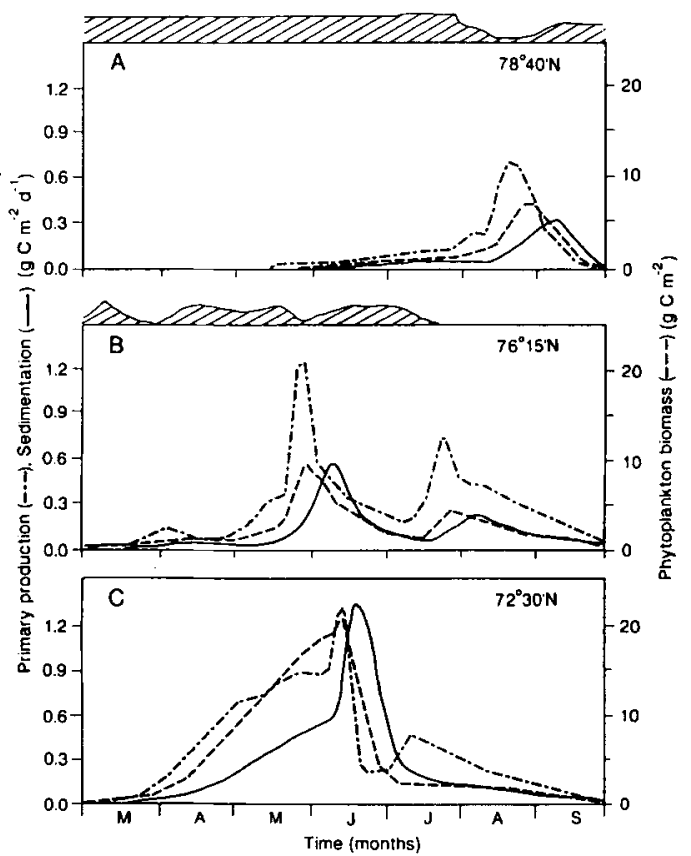

Fig. 6. Results from a mathematical model by Wassmann \& Slagstad (unpubl. results): Seasonal dynamics of primary production $(-\cdot-\cdot \cdot \cdot-)$, sedimentation $(-)\left(\mathrm{g} \mathrm{C} \mathrm{m}^{-2} \mathrm{~d}^{-1}\right)$ and suspended phytoplankton biomass (----) $\left(\mathrm{g} \mathrm{C} \mathrm{m}^{-2}\right)$ along a transect in the central Barents Sea.

ginal ice zone moves to the north during summer with the greatest retreat in the eastern Barents Sea. Interannual differences, however, are significant (Wadhams 1986). The spring phytoplankton bloom in the southern Barents Sea dominated by warm Atlantic Water takes place in May/June (Fig. 6C) and is dominated by diatoms, for example Chaetoceros socialis, and by $P$. pouchetii. Phytoplankton growth starts already in late March, but stabilisation of a shallow surface layer by solar insolation is slow in this area and hence phytoplankton biomass increases correspondingly slowly. A strong pulse of sedimentation during spring is usually encountered as zooplankton grazing pressure by the major herbivore Calanus finmarchicus is light. Grazing by this copepod, which also dominates in the Atlantic Water of the Norwegian Sea, was shown to counteract sedimentation (Peinert et al. 1987). In the southern part of the Barents Sea, zooplankton can expect a rather predictable development of the spring bloom during May/June (Fig. 6C). To what extent the bloom is influenced by grazing, however, depends both on the size of overwintering populations, especially C. finmarchicus, as well as on the advection of its copepodites from the Norwegian Sea into the southern Barents Sea (see below). The southern Barents Sea is a onepulse system since no additional autumn bloom takes place due to light limitation.

In the marginal ice zone further north and east the situation is different (Fig. 6A, B). If the seaice conditions allow for light penetration, the phytoplankton spring bloom starts earlier and develops more rapidly than in the southern Barents Sea. This is due to the rapid increase in stability caused by melting sea ice. Again, a strong pulse of sedimenting matter follows the spring bloom after nutrient limitation. If, however, winter nutrients are left at the end of the spring bloom due to a deterioration of the light conditions (caused by a new advance of the marginal ice zone), another, yet smaller bloom may take place later (Fig. 6B). The rapid development of the spring bloom in the marginal ice zone of the Barents Sea typically decouples phytoplankton development from zooplankton grazing (Eilertsen et al. 1989). This effect is most pronounced in the ice-covered North where a minor, lightlimited spring bloom may take place as late as in August/September during some years, followed presumably by a correspondingly small pulse in sedimentation. In other years, no bloom takes place at all when sea ice covers the northernmost areas until insolation reaches limiting values in September. Annual primary production decreases, thus, with increasing latitude, and food supply is more unpredictable in the northern as compared to the southern Barents Sea (Rey et al. 1987). Plant biomass may not be available every year, depending on the ice situation.

The major zooplankton species in the areas dominated by Arctic Water are C. glacialis and Calanus hyperboreus, and these species seem well adapted to an unpredictable food supply by a life-cycle of more than one year (Tande 1991). This makes them less vulnerable to seasonal and interannual variability in food supply. These copepods are much larger than C. finmarchicus and accordingly produce larger faecal pellets for which higher sinking velocities have to be assumed. It is thus not yet clear if their grazing on spring phytoplankton counterworks sedimentation to the same extent as that of $C$. finmarchicus.

Capelin (Mallotus villosus) is a commercially 
important fish that is also a key species in the southern and central Barents Sea. After spawning close to the coast of northern Norway and the Kola Peninsula. the capelin stocks migrate in the form of a 'front' northwards into the Barents Sea. Migrating capelin decimate zooplankton stocks in the southern and central Barents Sea. leaving behind only sparse numbers in the "wake". Considering the efficiency with which capelin deplete zooplankton stocks over a vast area (Skjoldal \& Rey 1989), their presence is likely to affect sedimentation patterns. The capelin stocks in the Barents Sea have been strongly reduced since 1987 as a result of fishing and increased predation by cod. Presumably zooplankton at present exerts greater control on the vertical flux than before, as grazing pressure and hence retention of essential elements during summer in the upper layers will have increased due to decreased sedimentation. The present situation in the Barents Sea might be shifted towards that encountered in the Norwegian Sea after the break-down of the herring stock in the sixties (see below).

The shallow areas of the Barents Sea differ from the deeper regions in as much as pelagic herbivores have to share food resources with epibenthic macrofauna. This holds true for the waters especially around Bjørnøya and Spitsbergen as well as in the eastern and southeastern part of the Barents Sea. Locally. some of the world's largest benthic biomass concentrations are found here (Zenkevitch 1963) exemplifying the tight pelago-benthic coupling characteristic of shallow, Arctic environments (Grebmeier et al. 1988: Høpner-Petersen 1989). Loss rates of phytoplankton by sedimentation in these areas may be of minor importance when compared to active removal by benthic suspension feeders. The biodeposition of pelagic suspended matter by the scallop Chlamys islandica. commonly found in the shallow parts of the Barents Sea, can locally exceed sedimentation by an order of magnitude (Vahl 1980). Further. the zooplankton of the banks south of Spitsbergen can be dominated by cirripede larvae during May/June (F. Rey pers. comm.) which indicates the important role of this benthic suspension feeder on the plankton of the area.

\section{Open Norwegian Sea}

The surface currents of the Norwegian Sea are strongly influenced by the warm saline water of the Norwegian Atlantic Current whose branches cover a large area of the central northeast North Atlantic. In the southwest an additional. Arctic Water source is supplied by the East Icelandic Current (Fig. 3). On the Norwegian coastal shelf, water from the Norwegian Coastal Current contributes to the northward flow. Periods with temperatures and salinities well below the long-term mean occurred in the East Icelandic Current in the late 1960 s and were recorded in the $1970 \mathrm{~s}$ thereafter in the Atlantic inflow to the Norwegian Sea (Dickson et al. 1975; Gammelsrød \& Holm 1984). A down-stream delay of about three years between the Rockall Channel in the southwest and the entrance to the Barents Sea in the northeast of the Norwegian Sea was recorded as well, suggesting that this event was advective (Dickson \& Blindheim 1984). This climatic anomaly represents one of the most persistent and extensive variations in ocean climate yet observed in this century (Dickson et al. 1988) and influences the plankton dynamics in the Norwegian Sea (Blindheim 1989).

The winter convection in the Norwegian Sea generally extends to as deep as $300 \mathrm{~m}$ and seasonally replenishes near-surface nutrient reserves. As the vernal stratification of the surface layers is almost entirely dependent on solar radiation. the spring phytoplankton bloom is delayed by one to two months as compared to the continuously stratified coastal waters (Halldal 1953; Rey 1981). The timing of stabilisation, however, varies between years, depending on meteorological conditions.

The Norwegian Sea is a transition zone with water sources of both Atlantic and Arctic origin. Accordingly the biota include both boreal and Arctic species but, as is typical for northern seas, are not very diverse. The spring phytoplankton bloom consists mainly of diatoms, but also years with dominance of naked flagellates were observed. Considerable interannual variations in the qualitative as well as the quantitative aspects of the spring development in the Norwegian Sea have been acknowledged (Paasche 1960). The summer vegetation is rather sparse and dominated by microflagellates, coccolithophorids and dinoflagellates, but is more diverse and represents a typical regenerating community. It is not known to what extent autumn blooms take place.

The Norwegian Sea is generally rich in macrozooplankton with copepods (C. finmarchicus, C. hyperboreus), various euphausiids (e.g. 
Meganyctiphanes norvegica) and pteropods ( $\mathrm{Lim}$ acina retroversa) being important grazers (Wiborg 1955). Østvedt (1955) observed neritic plankton to spread out as far as Ocean Weather Ship MIKE which is well within the Norwegian Sea proper. There, Lie (1968) observed large variations in the timing of maximum zooplankton concentrations (up to three months), possibly also due to advection from the Norwegian Coastal Current. Advection from the Norwegian Coastal Current and also along the axis of the Norwegian Current results in blurring spatial distribution patterns of Arctic and boreal zooplankton. C. finmarchicus maintains itself in the Norwegian Sea because of ontogenetic vertical migration. The overwintering population drifts southward at depth whereas feeding stages are moved northwards with surface water (Noji 1989).

Comparing vertical fluxes from oceanic environments of the Northeast Atlantic with those of the fjords and shelf is difficult because the former are derived from trap deployments below $500 \mathrm{~m}$ which are greatly reduced due to remineralization of matter in the upper hundreds of metres. The seasonal sedimentation of POC at $500 \mathrm{~m}$ depth on the Vøring Plateau in the Norwegian Sea off the Norwegian shelf at $67^{\circ} \mathrm{N}$ is shown in Fig. 5C. Seasonal maxima were generally found during summer with low sedimentation rates in spring and autumn. Three years of trap deployments, however, showed significant interannual variations. The single peaks recorded in April 1986 and November/December 1987 appear unexplained. Despite the scatter in the data, it is obvious that the "regular" seasonal maximum of vertical flux occurs in summer on the Vøring Plateau and is hence not related to the spring bloom, as is typical for shallow regions described above.

Microscopic analyses of trap collections indicate that the various identifiable biogenic components tend to have elevated fluxes at the time of the general seasonal maximum (Fig. 7). It appears that sedimentation on the Vøring Plateau is strongly influenced by zooplankton. Through the productive season, zooplankton feeding pressure is high and loss rates, accordingly, are low. The abundance of copepods over-wintering at depth and of those in small numbers present in the surface in late winter and their ability to respond to increases in food supply must be considered in order to assess grazer control of the phytoplankton spring bloom in the Norwegian
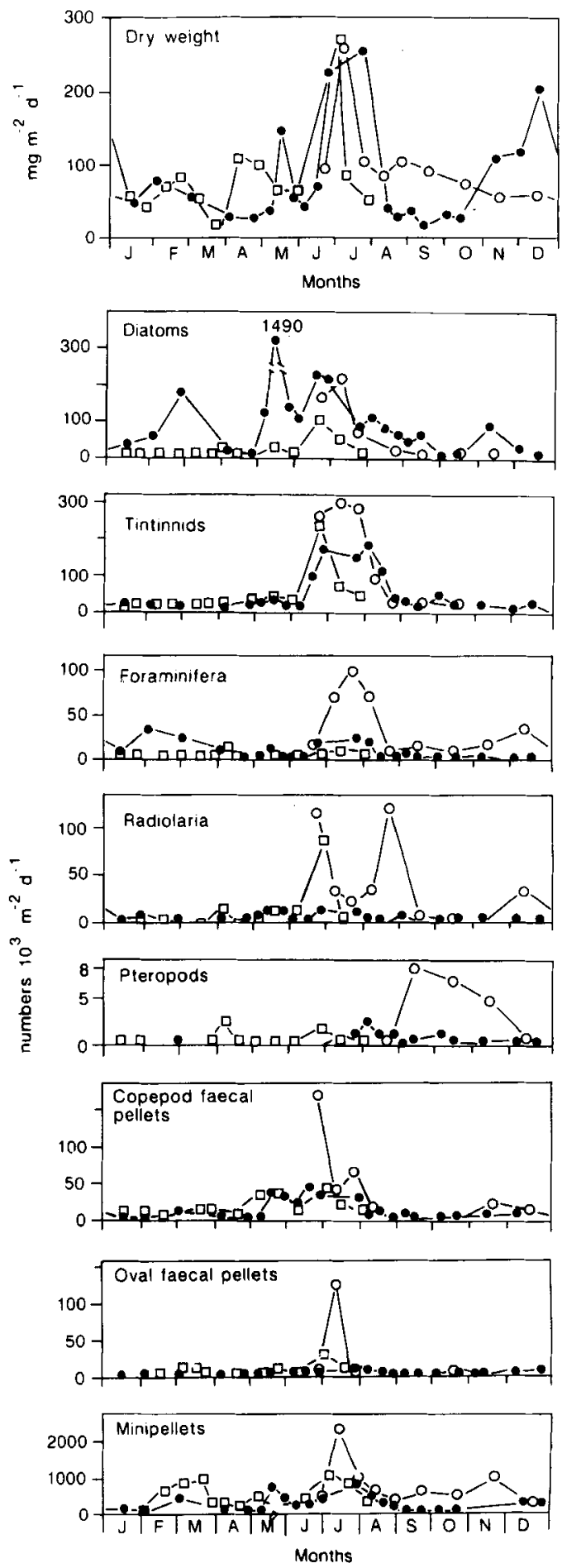

Fig. 7. Sedimentation rates at $500 \mathrm{~m}$ depth on the Vøring Plateau during 1986 (open circles), 1987 (filled circles), and 1988 (open squares). Total flux (dry weight) ( $\mathrm{mg} \mathrm{m}^{-2} \mathrm{~d}^{-1}$ ) and contributions of different biogenic particles (numbers $10^{3} \mathrm{~m}^{-2} \mathrm{~d}^{-1}$ ). Data replotted from Bathmann et al. (1990a). 
Sea (Peinert et al. 1989; Bathmann et al. 1990b). Spring phytoplankton biomass accumulation and sedimentation thus depends on the grazers and blooms may not take place each year. The trap data, never depicting spring flux maxima in various years indicate in fact that spring phytoplankton outbursts may be the exception from the rule in this region.

During summer, a pulse of faecal pellets was observed, presumably due to a declining recycling efficiency caused by ontogenetic migration of $C$. finmarchicus copepodites to greater depth (Bathmann et al. 1987). This event triggered a response in benthic metabolism (Graf 1989). Indirect evidence indicates that the presence of large copepod stocks counteract pellet sedimentation, although these are produced in large numbers (Smetacek 1980b). The tentative conclusion is that copepods themselves break up their faeces (named coprorhexy by Lampitt et al. 1990) and contribute organic material to the microbial network hence promoting recycling of waste products (Smetacek \& Pollehne 1986). However, repackaging of sinking material can also take place at mid-water depths as reflected by oval faecal pellets and minipellets at certain depth horizons (Bathmann et al. 1990a) (Fig. 7)

Detailed microscopy of Vøring Plateau trap samples reveal that not all particles sink out in concert nor are all flux patterns recurrent. The time series (Fig. 7) show, for example, that the pteropod flux maximum is in autumn in contrast to the summer maximum of the other biogenic components. Although not observed in 1987, the pteropod maximum may nevertheless be a typical feature for the Norwegian Current as it was found again in 1988 (Bathmann et al. 1990a) and was also described for the nearby Lofoten Basin (Honjo et al. 1987). Bathmann et al. (1991) show that intense feeding by dense swarms of reproducing pteropods enhance flux due to sinking out of feeding webs with adhering particles. After reproduction, mass mortality occurred which was reflected in large numbers of pteropod shells in sediment catches.

A shift of the seasonal maximum of the vertical flux towards summer/autumn seems to be typical for the oceanic areas dominated by the Norwegian Atlantic Current (Fig. 8A, B) which clearly separates them from the coastal and shelf waters of the Northeast Atlantic. Compared to the Voring Plateau, the flux maximum in the Lofoten Basin (about $650 \mathrm{~km}$ northeast of the Vøring Plateau deployment) occurs even later during autumn (Figs. 8A, B). Off Bjørnøya, west of the Barents Sea entrance, sedimentation rates are far higher as in the Northeast Atlantic proper; seasonality differs and winter values are greatly enhanced (Fig. 8A, B). This is explained by winterly sediment resuspension and subsequent cross shelf transport of nepheloid layers from the Barents Sea into the Norwegian Sea by dense bottom water (Midttun 1984; Honjo et al. 1988; Quadfasel et al. 1988).

\section{Western regions of the northeastern North Atlantic}

Greenland Sea and Fram Strait. - The water masses of this region consist primarily of two components: Very cold $\left(-1.5\right.$ to $\left.1.5^{\circ} \mathrm{C}\right)$ and low saline ( 34.0 to $34.6 \%$ ) water from the East Greenland Current and slightly warmer and more saline water from the Irminger and West Spitsbergen currents. The area is heavily covered by sea ice during most of the year, the seasonal and interannual variability of sea ice, however, is less pronounced in the Fram Strait and Greenland Sea area as compared to the Barents Sea (Fig. 2). Seaice dynamics are dominated by the Transpolar Current and the East Greenland Current which transports Polar Water and ice from the Polar Sea along the Greenland coast into the Greenland Sea and Icelandic areas. The ice coverage is still significant at $60^{\circ} \mathrm{N}$ in the western part of the Northeast Atlantic compared to an average latitude of sea ice in the Barents Sea of about $75^{\circ} \mathrm{N}$ on the eastern side. Heavy sea ice from the Polar Sea and the Fram Strait blocks the fjords of East Greenland, for example Scoresby Sound, for most of the year. The productivity of these fjords is, therefore, low.

Our knowledge about the relationship between plankton production and sedimentation in the Fram Strait and Greenland Sea is limited. However, primary production, zooplankton abundance and hence probably also the vertical flux vary much between cold and warm years in the waters off southern Greenland (Horsted 1989). Primary production is generally highest in the frontal regions between the East Greenland Current and the warmer water masses. The spring bloom starts in the outer parts of the fjords in southeast Greenland as early as March and maxima are found in April and July/August (Smidt 1979). Microzooplankton has its maximum in July 
Fig. 8. Sedimentation rates $\left(\mathrm{mg} \mathrm{m} \mathrm{m}^{-2} \mathrm{~d}^{-1}\right)$ of particulate organic carbon (POC) and particulate silicate (PSi) as obtained from deepmoored sediment traps in areas dominated by the Norwegian Atlantic Current and East Greenland Current. Data replotted from Honjo et al. (1987).

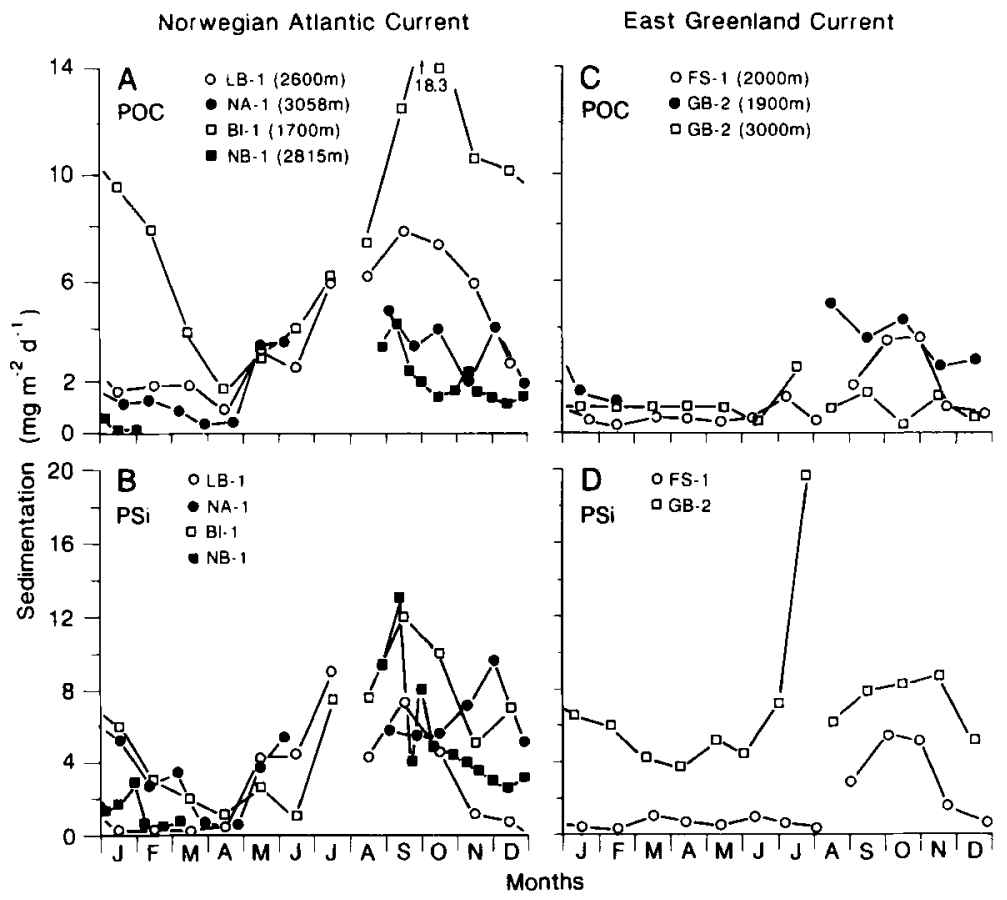

and the macrozooplankton has a somewhat longer-lasting maximum from June-July onwards. Phytoplankton growth in glacial fjords shows a pronounced seasonal cycle and is enhanced in the outer, more mixed areas as compared to the inner, stratified waters (Horsted 1989) where light penetration is lower due to turbidity brought about by the sediment load from glacial meltwater.

In the open waters of the Davis Strait the most important herbivores are the copepods $C$. finmarchicus, $C$. glacialis, $C$. hyperboreus and $O$. similis. The composition of the zooplankton and the timing of its development are strongly affected by hydrography and ice conditions. $C$. finmarchicus is an indicator of Atlantic Water, $C$. glacialis and $C$. hyperboreus are characteristic for Arctic Water, while Oithona similis indicates the region of the Polar Front and mixed waters (Pavshtiks 1968). Zooplankton development commences during June in coastal waters and in April to May in the Davis Strait. The timing between primary and secondary production off Greenland is coupled to variations of the East Greenland and Irminger currents that influence ice cover, temperature, and stratification as well as advection of nutrients and organisms. The distributions and abundances of for example cod, salmon and shrimps show accordingly long-term and short-term variations (Horsted 1989), and so should the vertical flux of particles.

Polynyas are regularly found in the marginal ice zone off East Greenland (Niebauer \& Alexander 1989). The nutrient rich, Polar Water of the Transpolar Current is exposed to insolation in these polynyas and the marginal ice zone and is transported into open waters (Spies et al. 1988). Along the drift of water exposed to sunlight, sequences of planktonic developments are found in space which would be found in time at an ice-free, subarctic station. As in the Barents Sea, diatoms and $P$. pouchetii are the dominating phytoplankton species (Gradinger 1987; Smith et al. 1987). Ice-algae from melting multi-year ice from the Polar Basin may add to the phytoplankton biomass present in polynyas (Melnikov \& Bondarchuk 1987). The zooplankton is dominated by larger forms such as $C$. finmarchicus, $C$. hyperboreus and C. glacialis (Barthel 1990; Smith \& Schnack-Schiel 1990); egg production and feeding take place prior to the spring phytoplankton bloom (Smith 1990) and secondary production within the marginal ice-zone can be high $(\mathrm{H}$. J. Hirche pers. comm.). The zooplankton community shares common features with those of the Barents Sea as well: Atlantic species with annual 
life cycles preferring the warmer water to the east of the marginal ice zone predominance (e.g. C. finmarchicus) are contrasted by Arctic species in the marginal ice zone and polynyas which prefer colder water and have a multi-annual life-cycle.

Sedimentation data from these regions are sparse and originate from deep-moored traps. POC sedimentation rates as well as seasonal variability in the Greenland Basin and the Fram Strait are lower (Fig. 8C) as compared to waters dominated by the Norwegian Atlantic Current (Honjo 1990). Sedimentation, however, increases during summer and for biogenic silica one episode of increased vertical flux was encountered by the Greenland Sea trap (Fig. 8D). It is not known to what extent the ice coverage of the deployment areas during the productive period might have limited primary production and hence sedimentation. Recent deployments including shallower traps, however, indicate a pronounced seasonal vertical flux pattern (B. v. Bodungen pers. comm.).

Icelandic waters. - The hydrography around Iceland is influenced by Atlantic Water from the Irminger Current and Polar Water from the East Greenland Current (Fig. 3). Whereas Atlantic Water and the Icelandic Coastal Current dominate the shelf and oceanic areas to the south and west of Iceland, the waters in the north and east of Iceland are influenced by a complicated mixture of different water masses. The latter area is a highly variable frontal zone fed by the Irminger Current (Atlantic Water), the East Icelandic Current (Arctic Water), the East Greenland Current (Polar Water) as well as the clockwise turning Icelandic Coastal Current (Fig. 3). Most of the fjords of Iceland are deep and well connected to the adjacent shelf.

During input of Polar Water, the marginal ice zone comes close to the northern Icelandic coast. Low primary production rates were observed during such years and attributed to increased stratification of surface water, preventing the supply of nutrients from below and hence constraining continued new production (Thóradóttir 1977). The spring phytoplankton bloom starts in the southern and western waters of Iceland in nearcoastal areas in late March, whereas further in offshore areas its advent is usually in the second half of May (Thóradóttir 1986). In the north, the spring phytoplankton bloom ends earlier during cold periods than during warmer periods, usually before the middle of June. Autumn blooms are generally not reported from Icelandic waters. The zooplankton biomass follows that of phytoplankton in the Atlantic Water and over wintering is of significance in the fjords (Astthórsson \& Jónsson 1988; Astthórsson 1990). The spring bloom of the areas to the south and west of Iceland is, thus, influenced by grazers. During periods when the influx of Atlantic Water is strong and the zooplankton stocks are rich, this may probably also be true for oceanic provinces to the north. Since new production is lower during times of dominating outbreaks of Polar Winter, less zooplankton is accordingly found as compared to warmer periods (Thóradóttir \& Astthórsson 1984).

Extensive changes in the physical, chemical and biological properties in the waters have been recorded especially north of Iceland, reflecting climatical variations (Thóradóttir 1977; Stefánsson \& Jacobsson 1989). While diatoms usually dominate the phytoplankton spring bloom in Icelandic waters, colonial stages of $P$. pouchetil increase markedly during the cold periods. Since the 1960s this species has dominated the phytoplankton community to the north of Iceland. The $P$. pouchetii blooms reflect anomalies in the silicate-nitrate relationship (Stefánsson 1990). To what extent $P$. pouchetii colonies are grazed by zooplankton, sink into the aphotic zone and/or are broken down by microbial degradation is still a matter of dispute (Huntley et al. 1987; Hansen et al. 1990; Estep et al. 1990). However, P. pouchetii colonies have been observed to sink rapidly in Arctic and subarctic waters of the Barents Sea (Wassmann et al. 1990), adding nutrient depletion of the euphotic zone and thus limiting further production in the waters north of Iceland.

The highly productive front areas off Iceland and Jan Mayen support large zooplankton stocks which have been the basis for large pelagic fisheries ( for example herring, capelin and blue whiting). The herring has played a key role as a planktonic carnivore in Icelandic waters and of the Norwegian Sea (summarised by Devold \& Jacobsen (1968) and Dragesund et al. (1980)). Herring feed mostly in the waters between Iceland, Jan Mayen and the Icelandic Gap Front during May to September. However, the northern Norwegian Sea, for example the waters west of Bjørnøya, is also a feeding ground. The herring must have had a pronounced influence on the vertical flux of biogenic matter by grazing on 
zooplankton and by producing faeces, as fish faeces can contribute significantly to vertical flux (Staresinic et al. 1983; Heussner et al. 1987).

As a consequence of increased stability due to increased supply of cold water from the East Greenland Current from 1966 on, productivity of the Icelandic Gap Front has since generally decreased (Stefánsson \& Jacobsson 1989). It can be speculated that climatic induced reduction in zooplankton stocks also resulted in decreased stocks of carnivores as zooplankton resources might be limited in relation to food requirements of zooplankton feeders, for example herring (Pavshtiks \& Timokhina 1972). The effect of the disappearance of herring on other stocks and the zooplankton community is difficult to assess and so far no observations are available which indicate that the herring has been replaced by any other major planktivore. No vertical flux data are available from Icelandic waters. We suggest that sedimentation today is different from that in the mid1960 s and before.

\section{Evaluation of case studies}

The case studies clearly indicate that the relationship between annual patterns of primary production and those of sedimentation can vary considerably. The factors determining vertical flux interact with one another so that flux rates and patterns can exhibit large regional and interannual variability. In the following we examine the role of the governing factors individually in order to assess their specific impact on processes governing particle production, modification and sedimentation.

\section{Nutrients, water column stability and spring phytoplankton growth rate}

The potential new production is dictated by depth of the mixed layer but also by initial nutrient concentrations. Nitrate is generally accepted to be the controlling nutrient species. Diatoms and also $P$. pouchetii blooms respond rapidly when ambient nitrate is exhausted and mass sedimentation is commonly observed. The deployment of ultra-clean methods to monitor essential trace elements has provoked a debate whether iron in particular is the limiting nutrient in some areas of the Pacific Ocean and the Antarctic (Martin \& Fitzwater 1988; Banse, 1990; Martin 1990; Dugdale \& Wilkerson 1990). This debate is beyond the scope of this paper and future results may elucidate a potential impact on the vertical flux of particles. At present, it could only be speculated that, for example, diatoms may respond in a different way to iron limitation compared to nitrate limitation. Aggregation and rapid sinking from surface layers following nitrate limitation (Smetacek 1985) may not be triggered if iron is the limiting element.

A shallow mixed layer in spring is a prerequisite for development of the spring bloom. The depth of this layer in relation to light supply determines the rate of biomass accumulation during this period (Smetacek \& Passow 1990). The shallowest mixed layers are found in sheltered waters but also along fronts between waters of different salinities, for instance on the borders of river plumes and at the edge of melting sea ice. Massive blooms covering restricted areas are characteristic of such shallow mixed layers, and blooms culminate as a result of ambient nutrient exhaustion. These are the blooms most likely to form aggregates on a large scale that sink out of the mixed layer rapidly (Smetacek 1985). The percentage of new production lost to the system via vertical flux is highest under such conditions. In contrast, spring growth that commences in a deep mixed layer deplenishes nutrients and accumulates biomass slowly. The impact of grazing is obviously much greater on a phytoplankton population growing slowly as compared to one growing rapidly. Accordingly, the percentage loss via sinking cells and phytodetritus is smaller and the proportion of organic material channelled to the grazer pools is larger. However, depending on the degree to which available nutrients are utilised, total new production can be much higher in regions with a deeper mixed layer, hence also the potential for support.

Although the average depth of the mixed layer is a characteristic feature of specific regions, it is still dependent on short-term weather conditions. In land-locked fjords, the annual variation will be restricted; in open ocean conditions, variation in the biomass accumulation rate can vary greatly. Thus, under cloudy, stormy conditions, mixing will be thorough and average cell division rates low. Under the influence of a stable high pressure zone, heating of the upper metres will lead to temporary stabilisation and rapid accumulation of biomass since cells and their progeny will continue to divide at maximal rates. One can assume that in such a situation, the thin, warmer water 
layers will not lie like a sheet over the colder winter water. Rather, the warming water will be susceptible to horizontal displacement and formation of warm water lenses on the kilometre scale. The horizontal distribution of algal biomass will be correspondingly patchy. Indeed, this mechanism is probably responsible for the patchy distribution of the spring bloom recorded in the Norwegian shelf by Peinert (1986a), along the Polar Front and in the marginal ice zone of the Barents Sea and Fram Strait (H. J. Hirche, pers. comm.) and also in the open Baltic during PEX 86 (Passow 1990).

Smetacek (1985) postulated that mass flux is preceded by aggregation of cells and chains. Aggregate formation in nutrient exhausted blooms has since been observed in nature (Kranck \& Milligan 1988; Alldredge \& Gotschalk 1989; Riebesell 1989). It follows that the higher the phytoplankton concentration the greater the speed of aggregate formation and hence also the proportion of the bloom lost to sedimentation. This is the case during blooms of sticky colonies of $P$. pouchetii (Wassmann et al. 1990). Evidence for such a relationship is circumstantial at present but we see little reason to suspect that it does not apply in nature. In this case horizontal patchiness of bloom biomass would result in even greater patchiness in vertical flux.

\section{Composition of phytoplankton}

Sediment trap data to date indicate that diatoms and coccolithophorids - both algae equipped with mineral covers - contribute a much greater proportion to vertical flux than flagellates without a mineral burden. This is illustrated by the situation described from the North Sea Fladen Ground in 1976 and in 1983: when diatoms dominated, heavy sedimentation was recorded whereas flux rates were very low when the colonial flagellate Corymbellus aureus dominated the spring bloom. The factors responsible for this inter-annual shift in dominance are unknown but their effect on vertical flux is obvious. The degree to which the latter situation can be classified as unusual also awaits clarification. The fate of another, much more widespread, colonial flagellate (Phaeocystis) appears to be both retention within the mixed layer as well as sedimentation. Thus, in the North Sea, huge masses of foam emanating from declining Phaeocystis blooms accumulate on the coast (Bätje \& Michaelis 1986), a phenom- enon which never occurs in the case of the larger diatom blooms that precede Phaeocystis. We conclude that this flagellate, following senescence of its blooms, does not sink out as readily as do diatoms but, under conditions not yet specified, can indeed settle out of the mixed layer as observed in the Barents Sea (Wassmann et al. 1990). Much more information is required on the sinking behavior of different phytoplankton groups and species to further our knowledge of vertical flux. In recent studies in the Baltic and the Barents Sea, Passow (1990) and Wassmann \& Rey (unpubl. data), respectively, found significant species-specific differences in sinking behavior within a mixed spring bloom population.

\section{The role of grazers}

As one moves from shallower to deeper water, the role of grazers increases in importance to an extent that grazing pressure can significantly retard bloom growth and hence prevent sinking out of cells and phytodetritus. Whether sedimentation occurs subsequent to heavy grazing in the form of herbivore faeces or whether it is retarded altogether depends on the type of grazer dominating this trophic level.

Protozoans, particularly the large forms that feed by extrusion of a feeding appendage (Jakobson \& Anderson 1986) can well exert significant grazing pressure on phytoplankton including large, chain-forming diatoms. Digestion in these organisms seems to be fairly thorough and faeces attributed to this group generally consist of empty frustules. These so-called minipellets can be an important vehicle for transporting whole diatom frustules to the deep sea (Gowing \& Silver 1985; Nöthig \& Bodungen 1989). However, we are far from quantifying the role of these organisms in pelagic systems. Their influence on sedimentation patterns is likely to be substantial and warrants investigation.

Field data (Bathmann et al. 1987; Peinert et al. 1987; Noji 1989) and laboratory experiments (Lampitt et al. 1990) suggest that copepod grazing can counteract sedimentation by keeping matter in suspension. Being widespread, more evenly distributed horizontally (for example euphausiids) and unable to undertake direct horizontal migrations, copepods cannot easily leave their feeding grounds. In this context, coprorhexy (mechanical destruction of their own and other's faeces; Lampitt et al. 1990) and coprophagy are 
important mechanisms. By conditioning feeding grounds they would ensure that resources are retained and recycled and not "wasted" by sedimentation to depths beyond the copepods' reach. The efficiency of retention would be intimately related to copepod population density and food availability and hence not solely dependent on the immediate growth environment. During spring, copepod over-wintering success, the timing of their ascent from hibernation, population density and grazing pressure in surface waters are factors that exert control on "successful" retention or loss by sedimentation of primary produced matter. This is also supported by a model of phytoplankton growth and sedimentation under varying influence of copepod grazing by Wassmann \& Slagstad (unpubl. results). Assuming that no zooplankton grazing takes place, the model indicates that total primary production is solely determined by physical factors and sedimentation is high (Fig. 9A). If the number of copepods in the model is increased (Fig. 9B, C), retention of suspended matter in the upper layers becomes more efficient, sedimentation decreases accordingly and the phytoplankton biomass maximum is lower as well. Biomass of grazers of the copepod type which is controlled by the copepod's overwintering success and advection during late winter and spring obviously has a dominating influence on the carbon flux in the southern Barents Sea. As a consequence, grazing pressure can be expected to be highly variable from year to year, as the maximum macrozooplankton biomass shows a wide range between 1.5 and $15 \mathrm{~g} \mathrm{C} \mathrm{m}^{-2}$ (Skjoldal et al. 1987).

Grazing by large, roving crustaceans such as euphausiids produces faeces that sink too rapidly for easy recycling at depths of their production. Thus these crustaceans inherently deplete their own and others' feeding grounds. To sustain large
Fig. 9. Results of a model run by Wassmann \& Slagstad (unpubl. results): The effect of zooplankton grazing during early spring (variation in overwintering success and advection) in Atlantic Water of the Barents Sea at $72^{\circ} 30^{\prime} \mathrm{N}$. The number of copepodite stage $\mathrm{V}$ are indicated. Primary production (-.....-) and sedimentation (-) in $\mathrm{g} \mathrm{C}$ $\mathrm{m}^{-2} \mathrm{~d}^{-1} ;$ suspended phytoplankton (----) and zooplankton biomass $(\cdots \cdots)$ in $\mathrm{g} \mathrm{C} \mathrm{m}^{-2}$.
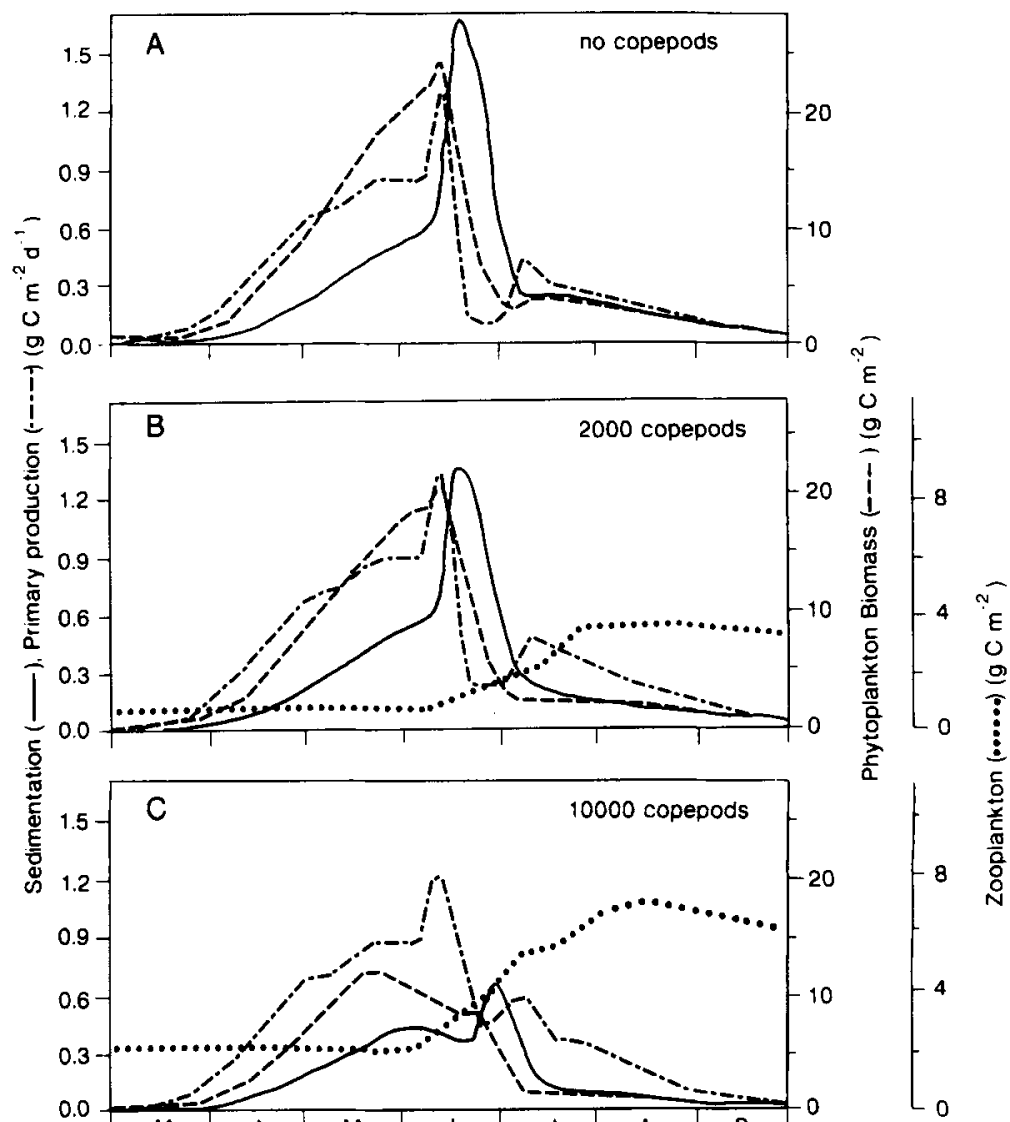
populations of this type of herbivore, however, horizontal migration to hitherto ungrazed blooms or continued new production by physical nutrient supply must compensate for losses via sedimented faeces. These organisms, however, also would benefit from copepods and other grazers that recycle matter in near surface layers.

Other herbivores such as pteropods and some gelatinous plankters (salps, appendicularians) are less predictable in their appearance, but may be abundant in very high numbers in some years and may significantly influence sedimentation. They all feed efficiently and non-selectively on small particles and, for example, faeces of salps can contribute significantly to the vertical flux (Bathmann 1988). Discharged pteropod feeding nets (Noji 1989) and abandoned appendicularian houses (Alldredge 1986) may play a role in accelerating losses by scavenging small and slower sinking particles. Finally, the organisms themselves (e.g. pteropods shells) can constitute a seasonally important fraction of settling inorganics (Bathmann et al. 1991). A further and indirect impact on sedimentation, which as yet can only be speculated upon, may result from changes in food web dynamics due to the presence of succession within herbivores. For the open Norwegian Sea, the maximum sedimentation, as encountered in late summer, could be related to a shift from a food web with copepods as major grazers towards a dominance of pteropods (Bathmann et al. 1990a).

During years of very high salp abundance, as observed non-periodically and non-predictably in Norwegian waters (Brattström 1972). we speculate that flux patterns would differ from normal years depending on the season of their appearance: if large salp biomass appeared early in spring, most of the phytoplankton biomass could leave the upper layers due to rapidly sinking faeces. This would leave copepods little chance to increase the size of their population. Such a scenario would result in a strong spring pulse in sedimentation and the observed summer or autumn pulse would be greatly reduced.

\section{Climatic change and the role of advection}

The fjord examples indicate that advection, driven by the local wind field, can determine the annual flux in these coastal systems. If, for example. the spring advective event referred to above had occurred weeks later, heavy sedi- mentation of the phytoplankton bloom could have been expected within the fjord. A second sedimentation pulse following an upwelling event could have taken place in addition to the first. We can postulate that in such open fjord systems, sedimentation patterns are governed by stochastic events, and hence are highly variable, whereas in closed fjords interannual variation will be lower due to limited advection.

In contrast to the subarctic North Pacific, the Northeast Atlantic on the whole can be viewed as a huge advective flow-through system. The major impact of this large scale latitudinal advection along a gradient of physical environmental conditions on sedimentation will be different as compared to the direct influence in the fjords. It is the advection of grazers to latitudes eventually unfavourable for their reproductional success which we believe to be important. The Barents Sea provides examples of this: the number of copepods advected from the Norwegian Sea varies interannually due to variations of the inflow of Atlantic Water (Blindheim \& Loeng 1981). The grazing pressure on spring phytoplankton will vary accordingly.

Long-term changes in the location and strength of major current systems influence the North Atlantic as a whole (Parsons \& Lalli 1988). Colebrook (1978) and Taylor (1978) observed that zooplankton is less abundant when the influence of the North Atlantic Current on the Northeast Atlantic is weak. Also, periods of hydrographic anomalies in the Norwegian and Barents seas do have implications for the pelagic food web. As a result of increased stratification due to a strengthening of the East Icelandic Current, primary and secondary production has decreased in the Icelandic Gap Front and herring stocks have disappeared. Although fishing was involved in the decline of herring stocks, there is reason to believe that variability in the pelagic system due to changed hydrographical conditions contributed to the observed change as well. A similar development was observed in the Barents Sea. Here, capelin disappeared as a result of climatically forced changes in zooplankton stock and fishing pressure. The pelago-benthic coupling and the food production for fish is strongly influenced by lateral transport of Atlantic Water into the southern Barents Sea (Fig. 9) and, thus, subject to climatic variations (Blindheim \& Loeng 1981; Skjoldal \& Rey 1989). The reasons for this variability are as yet poorly understood, but we specu- 
late that the pelago-benthic coupling in the Nordic Seas may have changed significantly since the decline of the herring and capelin stocks. Also, vertical flux may have decreased during recent years since coprophagy and coprorhexy of rich and well-structured zooplankton communities result in retention of food sources in the upper layers. The vertical flux studies accomplished during recent years may, thus, not be representative for previous periods with large abundances of pelagic fishes such as herring and capelin. Since the Norwegian and Barents seas experience large climatic and biological variations, no 'normal' pattern of production and sedimentation can be derived from a few annual studies.

The dominant copepods in the North Pacific differ in their life cycles from those in the Atlantic. One school of thought suggests that this difference is the underlying cause for the striking differences in annual cycles of phytoplankton (Frost et al. 1983; Frost 1987). In the subarctic North Pacific gyre, nutrient reserves (nitrate) are never exhausted and spring blooms do not occur. This is different in the North Atlantic. An establishment of the Pacific copepods in the North Atlantic, following from this reasoning, would entirely change its biology towards those patterns observed in the Pacific. We tend to believe, however, that this would have been 'tested out' in the course of evolution and we rather suggest that the cause for the difference lies in the advective nature of the Atlantic as compared to the Pacific. This different nature of the North Atlantic may not allow the establishment of overwintering copepod populations that are tightly geared to the seasonal production regime in the overlying surface layers as in the Pacific. Colebrook (1985) has pointed out that inter-annual variation in copepod biomass is governed by the size of the overwintering population. Peinert et al. (1987, 1989) suggest that this might hold true for the Norwegian Sea and the model of Wassmann \& Slagstad (unpubl. results) suggest that this is the case for the Barents Sea as well. If the seasonally first appearing copepods first serve to condition their environment by their activity in such a way as to open and maintain an adequate niche for their progeny, the size of the initial stock would indeed determine reproductive success in that year. Such biological gearing within populations and between trophic levels could be affected in unexpected ways by variability of the physicochemical environment. It is the task of future studies to establish such mechanisms and unravel the various processes at work in shaping and driving marine pelagic systems. Information on vertical flux will continue to be a prerequisite for furthering our understanding of pelagic systems in this context.

Acknowledgements. - P. Wassmann was supported by the Norwegian Research Council for Science and the Humanities (NAVF) and the Norwegian Ministry of the Environment. This publication is a contribution from the Norwegian Research Program for Marine Arctic Ecology (Pro Mare), publication No. 91 of the Sonderforschungsbereich 313. University of Kiel, and No. 332 of the Alfred-Wegener-Institute for Polar and Marine Research, Bremerhaven.

\section{References}

Alldredge. A. L. 1986: Aggregate dynamics: Biological processes, which form, alter and destroy aggregates in the ocean. Pp. 109-130 in Alldredgc, A. L. \& Hartwig, E. O. (eds.): Aggregate dynamics in the sea: Workshop report. American Institute of Biological Sciences, Washington D.C.

Alldredge, A. L., Silver, M. W. 1988: Characteristics, dynamics and significance of marine snow. Prog. Oceanogr. 20, 41-82.

Alldredge, A. L. \& Gotschalk, C. 1989: Direct observations of the flocculation of diatom blooms: characteristics, settling velocities and formation of diatom aggregates. Deep-Sea Res. 36, 159-171

Astthórsson, O. S. 1990: Ecology of the euphausiids Thyssanoessa raschii, $T$. inermis and Meganyctiphanes norvegica in Isafjord-deep, northwest Iceland. Mar. Biol. 107, 147-157.

Astthórsson, O. S. \& Jónsson, G. S. 1988: Seasonal changes in abundance in Isafjord-deep, northwest Iceland, in relation to chlorophyll $a$ and hydrography. Counc. Meet. Int. Counc. Explor. Sea 1988/L:3. 18 pp.

Bätje, M. \& Michaelis, H. 1986: Phaeocystis pouchetii blooms in East Frisian coastal waters German Bight. North Sea. Mar. Biol. 93, 21-27.

Banse, K. 1990: Does iron really limit phytoplankton production in the offshore sub-arctic Pacific? Limnol. Oceanogr. 35, 772-775.

Barthei, K.-G. 1990: Relationships of food uptake and body components of Calanus finmarchicus, $C$. glacialis and $C$. hyperboreus to particulate matter and water characteristics in the Fram Strait. Polar Biol. 10, 343-350.

Bathmann, U. 1988: Mass occurrence of Salpa fusiformis in the spring of 1984 off Ireland: implication for sedimentation processes. Mar. Biol. 97, 127-135.

Bathmann, U., Noji. T. T., Voss, M. \& Peinert, R. 1987: Copepod fecal pellets: abundance, sedimentation and content at a permanent station in the Norwegian Sea in May/June 1986. Mar. Ecol. Prog. Ser. 38, 45-51.

Bathmann, U., Peinert, R. \& Bodungen, B. v. 1990a: Pelagic origin and fate of sedimenting particles in the Norwegian Sea. Prog. Oceanogr. 24, 117-125.

Bathmann, U., Noji, T. \& Bodungen, B. v. 1990b: Copepod grazing potential in late winter in the Norwegian Sea - a factor in the control of spring phytoplankton growth? Mar. Ecol. Prog. Ser. 60, 225-233.

Bathmann, U., Noji, T. \& Bodungen, B. v. 1991: Sedimentation of pteropods in the Norwegian Sea in autumn. Deep-Sea Res. $10,1341-1351$. 
Berger, W., Smetacek, V. \& Wefer, G. 1989: Ocean productivity and paleoproductivity. Pp. 1-34 in Berger, W., Smetacek, V. \& Wefer, G. (eds.): Productivity of the ocean: present and past. John Wiley \& Sons, New York.

Blindheim, J. \& Loeng, H. 1981: On the variability of Atlantic influence in the Norwegian and Barents Sea. Fiskdir. Skr. Ser. Havunders. 17, 161-189.

Blindheim, J. 1989: Ecological features of the Norwegian Sea. Pp. 366-401 in Rey, L. \& Alexander, V. (eds.): Proc. 6th Conf. Com. Arctique Internatl, 13-15 May 1986. E. J. Brill, Leiden.

Braarud, T., Gaarder, R. K.\& Nordli, O. 1958: Seasonal changes in the phytoplankton at various points of the Norwegian west coast. Fiskdir. Skr. Ser. Hauunders. 13.77 pp.

Brattström, H. 1972: On Salpa fusiformis Cuvier (Thalaciacae) in Norwegian coastal and off-shore waters. Sarsia 48, 71-90.

Brewer, P. G., Bruland, K. W., Eppley, R. W. \& McCarthy. J. J. 1986: The Global Ocean Flux Study (GOFS): Status of the U.S. GOFS Program. Eos 67, 827-832.

Cadée, G. C. 1985: Macroaggregates of Emiliana huxleyi in sediment traps. Mar. Ecol. Prog. Ser. 24, 193-196.

Cadé, G. C. 1986: Organic carbon in the water column and its sedimentation, Fladen Ground (North Sea). Neth. J. Sea Res. 20, 347-358.

Colebrook, J. M. 1978: Continuous plankton records: zooplankton and environment, North-East Atlantic and North Sea: 1948-1975. Oceanol. Acta 1, 9-23.

Colebrook, J. M. 1985: Continuous plankton records: overwintering and annual fuctuations in the abundance of zooplankton. Mar. Biol. 84, 261-265.

Davies, J. M. \& Payne, R. 1984: Supply of organic matter to the sediment in the northern North Sea during a spring phytoplankton bloom. Mar. Biol. 78, 315-324.

Deuser, W. G. 1988: Variability of hydrography and particle flux: transient and long-term relationships. Pp. 179-193 in Degens, E. T., Izdar, E. I., Honjo, S. (eds.): Particle flux in the ocean. Mitt. Geol.-Paläont. Inst., Univ. Hamburg. SCOPE/UNEP Sonderband 62.

Deuser, W. G. \& Ross, E. H. 1980: Seasonal changes in the flux of organic carbon to the deep Sargasso Sea. Nature (Lond.) 283. 364-365.

Devold, F. \& Jacobson, J. 1968: The formation and disappearance of a stock unit of Norwegian herring. Fiskdir. Skr. Ser. Havunders. 15, 1-22

Dickson, R. R., Lamb, H. H. \& Malmberg, S. A., Colebrook 1975: Climatic reversal in the northern north Atlantic. Nature (Lond.) 256, 479-482.

Dickson, R. R. \& Blindheim, J. 1984: On the abnormal hydrographic conditions in the European Arctic in the 1970s. Rapp. P. -v. Réun. Cons. Int. Explor. Mer 185, 201-213.

Dickson, R. R., Meinke. J., Malmberg, S.-A. \& Lee, A. J. 1988: The 'great salinity anomaly' in the northern North Atlantic 1968-1982. Prog. Oceanogr. 22, 103-151.

Dragesund, O. . Hamre, J. \& Ulltang. $\varnothing .1980$ : Biology and population dynamics of the Norwegian spring-spawning herring. Rapp. P.-v. Réun. Cons. Int. Explor. Mer 177, 43-71.

Dugdale, R. C. \& Wilkerson. F. P. 1990: Iron addition experiments in the Antarctic: A reanalysis. Global Biochem. Cycles 4, 13-19.

Eilertsen, H. C., Schei. B. \& Taasen, J. 1981: Investigations on the plankton community of Balsfjorden, northern Norway. Sarsia 66, 129-141.

Eilertsen, H. C., Tande, K. \& Hcgseth, E. N. 1989: Potential of herbivorous copepods for regulating the spring phytoplankton bloom in the Barents Sca. Rapp. P.-v. Réun. Cons. Int. Explor. Mer 188, 154-163.

Eppley, R. \& Peterson, B. J. 1979: Particulate organic flux and planktonic new production in the deep ocean. Nature (Lond.) $282,677-680$.

Estep, K. W., Nejstgaard, J. C. \& Skjoldal, H. R. 1990: Grazing of copepods upon Phaeocystis colonies as a function of the physiological state of the prey. Mar. Ecol. Prog. Ser. 67, 235249.

Frost, B. W., Laury, M. R. \& Hasset, R. P. 1983: Feeding behavior of large calanoid copepods Neocalanus cristatus and N. plumchrus from the subarctic Pacific Ocean. Deep-Sea Res. 30, 1-13.

Frost, B. W. 1987: Grazing control of phytoplankton stock in the open subarctic Pacific Ocean: A model assessing the role of mesozooplankton, particularly the large copepods Neocalanus spp. Mar. Ecol. Prog. Ser. 39, 49-68.

Gammelsrød, T., Holm, A. 1984: Variations of temperature and salinity at Station $\mathrm{M}\left(66^{\circ} \mathrm{N}, 2^{\circ} \mathrm{E}\right)$ since 1948 . Rapp. P.-v. Réun. Cons. Int. Explor. Mer 185, 188-200.

Gieskes, W. W. C. \& Kraay, G. W. 1986: Analysis of phytoplankton pigments by HPLC before, during and after mass occurrence of the microflagellate Corymbellus aureus during the spring bloom in the open northern North Sea in 1983. Mar. Biol. 92, 45-52.

GOFS (1989): Sediment trap technology and sampling. Report of the U.S. GOFS working group of sediment trap technology and sampling, Woods Hole. 93 pp.

Gowing, M. M., Silver, M. W. 1985: Minipellets: a new and abundant size class of marine fecal pellets. J. Mar. Res. 43, 395418.

Graf, G. 1989: Benthic-pelagic coupling in a deep-sea benthic community. Nature (Lond.) 341, 437-439.

Gradinger, R. 1986: Die Phytoplanktonverteilung in der Framstraße zwischen Grönland und Spitzbergen. Diplom Thesis. Univ. Kiel. 94 pp.

Grebmeier, J. M., McRoy, C. P. \& Feder, H. M. 1988: Pelagicbenthic coupling on the shelf of the northern Bering and Chukchi Sea I. Food supply and benthic biomass. Mar. Ecol. Prog. Ser. 48, 57-67.

Halldal, P. 1953: Phytoplankton investigations from weather ship $M$ in the Norwegian Sea, 1948-49. Hoalrdd Skr. 38. 91 pp.

Hansen, B. Tande, K. \& Berggreen, U. C. 1990: On the trophic fate of Phaeocystis pouchetii (Hariot). III. Functional responses in grazing demonstrated on juvenile stages of $\mathrm{Cal}$ anus finmarchicus (Copepoda) fed diatoms and Phaeocystis. J. Plankion Res. 12, 1173-1187.

Heinrich, A. K. 1962: The life histories of plankton animals and seasonal cycles of plankton communities in the oceans. J. Cons. Int. Explor. Mer 27, 15-24.

Heussner, S., Monaco, A. \& Fowler, S. W. 1987: Characterisation and vertical transport of settling biogenic particles in the northwestern Mediterranean. Pp. 127-147 in Degens. E. T., Izdar, E. I. \& Honjo, S. (eds.), Particle flux in the ocean. Mitt. Geol.-Paläont. Inst., Univ. Hamburg, SCOPE/UNEP Sonderband 62.

Honjo, S. 1990: Particle fluxes and modern sedimentation in polar oceans. Pp. 687-739 in Smith, W. O. (ed.): Polar Oceanography. Academic Press. New York.

Honjo, S., Manganini, S. J., Karowe, A. \& Woodward, B. L. 1987: Particle fluxes, North-Eastern Nordic Seas: 1983-1986, Woods Hole Oceanogr. Inst. Tech. Rept. WHOI-87-17. 85 pp. Honjo, S., Manganini, S. J. \& Wefer, G. 1988: Annual particle 
flux and a winter outburst of sedimentation in the northern Norwegian Sea. Deep-Sea Res. 35, 1223-1234.

Hopkins, C. C. E., Tande, K. S., Grønvik, S., Sargent, J. R. \& Schweder, T. 1985: Ecological investigations of the zooplankton community of Balsfjorden, Northern Norway: Growth. and quantification of condition, in relation to over-wintering and food supply in Metridia longa, Calanus finmarchicus, Thysanoessa inermis and Thysanoessa raschi. Pp. 83-102 in Gray, J. S. \& Christensen, M. E. (eds.): Marine biology of polar regions and effect of stress on marine organisms. John Wiley and Sons, New York.

Horsted, S. A. 1989: Some features of oceanographic and biological conditions in Greenland waters. Pp. 456-476 in Rey, L. \& Alexander, V. (eds.): Proc. 6th Conf. Com. Arctique Internat., 13-15 May 1985. E. J. Brill, Leiden.

Huntley, M., Tande, K. \& Eilertsen, H. C. 1987: On the trophic role of Phaeocystis pouchetii (Hariot). II. Grazing of Calanus hyperboreus (Krøyer) on diatoms and different size categories of P. pouchetii. J. Exp. Mar. Biol. Ecol. 110, 197-212.

Høpner-Petersen, G. 1989: Benthos, an important compartment in northern aquatic ecosystems. Pp. 162-178 in Rey, L. \& Alexander, V. (eds.): Proc. 6th Conf. Com. Arctique Internat. E. J. Brill, Leiden.

Jacobson, D. M. \& Anderson, J. M. 1986: Thecate heterotrophic dinoflagellates: feeding behavior and mechanisms. J. Phycol. 22, 249-258.

Koblentz-Mishke, O. J., Volkovinsky, V. V. \& Kabanova, J. K. 1970: Plankton primary production of the world ocean. Pp. 183-193 in Wooster, W. (ed.): Scientific Exploration of the South Pacific, Proceedings of the symposium, Nat. Acad. Sci., Washington, D.C.

Kranck, K. \& Milligan, T. G. 1988: Macroflocs from diatoms: in situ photography of particles in Bedford Basin, Nova Scotia. Mar. Ecol. Prog. Ser. 44, 183-189.

Lampitt, R. S., Noji, T. \& Bodungen, v. B. 1990: What happens to zooplankton fecal pellets? Implications for material flux. Mar. Biol. 104, 15-23.

Lie, U. 1968: Variation in the quantity of zooplankton and propagation of $C$. finmarchicus at station $\mathrm{M}$ in the Norwegian Sea 1959-66. Fiskdir. Skr. Ser. Hauunders. 14, 121-128.

Lindahl, O. 1987: Plankton community dynamics in relation to water exchange in the Gulmarfjord, Sweden. Ph.D. thesis, Univ. Stockholm. 138 pp.

Lutter, S., Taasen, J. P., Hopkins, C. C. E. \& Smetacek, V. 1989: Phytoplankton dynamics and sedimentation processes during spring and summer in Balsfjord, Northern Norway. Polar Biol. $10,113-124$.

Martin, J. H. 1990: Iron in Antarctic waters. Nature (Lond.) 345, 156-158.

Martin, J. H. \& Fitzwater, S. E. 1988: Iron deficiency limits phytoplankton growth in the north-east Pacific subarctic. Nature (Lond.) 331, 341-343.

Melnikov, A. \& Bondarchuk, L. L. 1987: Ecology of mass accumulation of colonial diatom algae under drifting Arctic ice. Oceanology 27, 233-236.

Midttun, L. 1984: Formation of heavy bottom water in the Barents Sea. Counc. Meet. Int. Counc. Explor. Sea I984/C. I7. 9 pp.

Niebauer, H. J., Alexander, V. 1989: Current perspectives on the role of ice margins and polynyas in high latitude ecosystems. Pp. 121-144 in Rey, L. \& Alexander, V. (eds.): Proc. 6th Conf. Com. Arctique Internat. , 13-15 May 1985. E. J. Brill, Leiden.

Nöthig, E.-M. \& Bodungen, B. v. 1989: Occurrence and vertical flux of faecal pellets of probably protozoan origin in the south- eastern Weddell Sea (Antarctica). Mar. Ecol. Prog. Ser. 56, 281-289.

Noji, T. 1989: The influence of zooplankton on sedimentation in the Norwegian Sea. Ber. Sonderforschungsbereich 313, Univ. Kiel 17.183 pp.

Østvedt, O. J. 1955: Zooplankton investigations from the weather ship M in the Norwegian Sea. Hvalrad. Skr. 40. 93 pp.

Paasche, E. 1960: Phytoplankton distribution in the Norwegian Sea in June. Fiskdir. Skr. Ser. Havunders. $12.77 \mathrm{pp.}$

Parsons, T. R. \& Lalli, C. M. 1988: Comparative oceanic ecology of the plankton communities of the subarctic Atlantic and Pacific oceans. Oceanogr. Mar. Biol. Ann. Rev. 1988, 317-359.

Passow, U.1990. Vertikalverteilung und Sedimentation von Phytoplanktonarten in der mittleren Ostsee während des Frühjahres 1986. Ber. Inst. Meereskunde, Kiel. 203 pp.

Pavshtiks, E. A. 1968: The influence of currents upon seasonal fluctuation in the plankton of the Davis Strait. Sarsia 34, 383 392.

Pavshtiks, E. A. \& Timokhina, A. F. 1972: History of investigations on plankton in the Norwegian Sea and main results of Soviet investigations. Proc. R. Soc. Edinburgh 73, 267-278.

Peinert, R. 1986a: Saisonale und regionale Aspekte der Produktion and Sedimentation von Partikeln im Meer. Ber. Son. derforschungsbereich 313, Univ. Kiel 2. 108 pp.

Peinert, R. 1986b: Production, grazing and sedimentation in the Norwegian Coastal Current. Pp. 361-374 in Skreslet, S. (ed.): The role of freshwater outflow in coastal marine ecosystems. Springer Verlag, Berlin.

Peinert, R., Bathmann, U., Bodungen, B. v. \& Noji, T. 1987: The impact of grazing on spring phytoplankton growth and sedimentation in the Norwegian Current. Pp. 149-164 in Degens, E. T., Izdar, E. I. \& Honjo, S. (eds.): Particle flux in the ocean. Mitt. Geol.-Paläont. Inst., Univ. Hamburg, SCOPE/UNEP Sonderband 62.

Peinert, R., Bodungen, B. v. \& Smetacek, V. 1989: Food web structure and loss rates. pp. 34-48 in Berger, W., Smetacek, V. \& Wefer, G. (eds.): Productivity of the ocean: present and past. John Wiley and Sons, New York.

Platt, T., Harrison. W. G., Lewis, M. L., Li, W. K. W., Sathyendranath, S., Smith, R. \& Vezina, A. F. 1988: Biological production and the oceans: the case for a consensus. Mar. Ecol. Prog. Ser. 52, 77-88.

Quadfasel, D., Rudels, B. \& Kurz, K. 1988: Outflow of dense water from a Svalbard fjord into the Fram Strait. Deep-Sea Res. 35, 1143-1150.

Rey,F. 1981: The development of the spring phytoplankton outburst at selected sites off the Norwegian coast. Pp. 649-680 in Satre, R. \& Mork, M. (eds.): The Norwegian Coastal Current, Univ. Bergen.

Rey, F. \& Loeng, H. 1985: The influence of ice and hydrographic conditionson the development of phytoplankton in the Barents Sea. Pp. 49-63 in Gray, J. S. \& Christensen, M. E. (eds.): Marine biology of polar regions and effect of stress on marine organisms. John Wiley and Sons, New York.

Rey,F., Skjoldal, H. R. \& Slagstad, D. 1987: Primary production in relation to climatic changes in the Barents Sea. Pp. 29-46 in Loeng, H. (ed.): The effect of oceanographic conditions on distribution and population dynamics of commercial fish stocks in the Barents Sea. Proc. 3rd Soviet-Norwegian Symp., Murmansk, 26-28 May 1986. Institute of Marine Research, Bergen.

Riebesell, U. 1989: Comparison of sinking and sedimentation rate measurements in a diatom winter/spring bloom. Mar. Ecol. Prog. Ser. 54, 109-119. 
Sætre, R. \& Mork. M. 1981: The Norwegian Coastal Current Univ. Bergen. 795 pp.

Skjoldal, H. R. \& Wassmann, P. 1986: Sedimentation of particulate organic matter and silicium during spring and summer in Lindåspollene, western Norway. Mar. Ecol. Prog. Ser. 30. $49-63$.

Skjoldal, H. R., Hassel, A., Rey, F. \& Loeng, H. 1987: Spring phytoplankton development and zooplankton reproduction in the central Barents Sea in the period 1979-1984. Pp. 59-89 in Loeng. $H$. (ed.): The effect of oceanographic conditions on distribution and population dynamics of commercial fish stocks in the Barents Sea. Proc. 3rd Soviet-Norwegian Symp.. Murmansk. 26-28 May 1986. Institute of Marine Research. Bergen.

Skjoldal, H. R.\& Rey, F. 1989: Pelagic production and variability of the Barents Sea ecosystem. Pp. 243-283 in Sherman, K. \& Alexander, L. M. (eds.): Biomass and geography of large marine ecosystems. Westview Press. Boulder, Colorado.

Smetacek, V. 1980a: Annual cycle of sedimentation in relation to plankton ecology in western Kiel Bight. Ophelia, Suppl. I, 65-76.

Smetacek, V. 1980b: Zooplankton standing stock. copepod faecal pellets and particulate detritus in Kiel Bight. Estuar. Coast. Mar. Sci. 11, 477-490.

Smetacek, V. 1985: Role of sinking in diatom life-history cycles: ecological. evolutionary and geological significance. Mar. Biol. 84, 239-251.

Smetacek, V., Bröckel. K. v.. Zeitzschel, B. \& Zenk. W. 1978: Sedimentation of particulate matter during a phytoplankton spring bloom in relation to the hydrographical regime. Mar. Biol. 47, 211-226

Smetacek, V., Bodungen, B. v. Knoppers, B., Peinert, R., Pollehne, F. Stegmann. P. \& Zeitzschel, B. 1984: Seasonal stages characterizing the annual cycle of an inshoie pelagic system. Repp. P.-v. Réun. Cons. Int. Explor. Mer 183, 126-135.

Smetacek, V. \& Pollehne. F. 1986: Nutrient cycling in pelagic systems: a reappraisal of the conceptual framework. Ophelia 26. $401-428$

Smetacek, V. \& Passow, U. 1990: Spring bloom initiation and Sverdrup's critical depth model. Limnol. Oceanogr. 35. 228 234.

Smidt, E. L. B. 1979: Annual cycles of primary production and of zooplankton at southwest Greenland. Medd. Gronl., Bioscience I. 1-53.

Smith. S. L. 1990: Egg production and feeding by copepods prior to the spring bloom of phytoplankton in Fram Strait. Greenland Sea. Mar. Biol. 106. 59-69

Smith, S. L. \& Schnack-Schiel. S. B. 1990: Polar Zooplankton. Pp. 527-598 in Smith. W. O. (ed.): Polar Oceanography. Academic Press. New York.

Smith. W. O., Baumann. M. E. M. . Wilson, D. L. \& Aletsee, L. 1987: Phytoplankton biomass and productivity in the marginal ice zone of the Fram Strait during summer of 1984. J. Geophys. Res. 92, $6777-6786$.

Spies. A., Brockmann. U. H. \& Kattner. G. 1988: Nutrient regimes in the marginal ice zone of the Greenland Sea in summer. Mar. Ecol. Prog. Ser. 47. 195-204.

Staresinic, N.. Farrington. J., Gagosian, R. B. Clifford. C. H. \& Hulburt, E. M. 1983: Downward transport of particulate matter in the Peru upwelling: role of the anchoveta Engraulis ringens. Pp. 22-240 in Suess. E. \& Thiede. J. (eds.): Coastal upwelling: Its Sedimentary Record. Plenum Press, New York.

Stefánsson. U. 1990: Anomalous silicate-nitrate relationships associated with Phaeocystis pouchetii blooms. Eos 71(2): 77.

Stefánsson. U. \& Jacobson, J. 1989: Oceanographic variations in the Iceland Sea and their impact on biological conditions. Pp. 427-455 in Rey. L. \& Alexander. V. (eds.): Proc. 6th Conf. Com. Arctique Internat., 13-15 May 1985. E. J. Brill, Leiden.

Suess, E. 1980: Particulate organic carbon fux in the oceans: surface productivity and oxygen utilization. Nature (Lond.). 288, 260-263.

Sundby. S. 1984: Influence of bottom topography on the circulation at the continental shelf of northern Norway. Fiskdir. Skr. Ser. Haunders. 17. 501-519.

Tande. K. S. 1991: Calanus in North Norwegian fjords and in the Barents Sea. Pp. 389-407 in Sakshaug, E. Hopkins, C. C. E. \& Øritsland, N. A. (eds.): Proceedings of the Pro Mare Symposium on Polar Marine Ecology, Trondheim, 12-16 May 1990. Polar Research 10(2).

Taylor, A. H. 1978: Long-term changes in North Atlantic Current system and their biological implication. Proc. R. Soc. Edinburgh 76. 223-243.

Thóradóttir. T. 1977: Primary production in northern Icelandic waters in relation to recent climatic changes. Pp. 655-665 in Dunbar, M. J. (ed.): Polar Oceans. Arctic Institute of America, Canada.

Thóradóttir. T, 1986: Timing and duration of spring blooming south and southwest of Iceland. Pp. 345-360 in Skreslet. S. (ed.): The role of freshwater outflow in coastal marine ecosystems. Springer Verlag, Berlin

Thóradótir. T. \& Astthórsson. O. S. 1984: Chlorophyll $a$ and zooplankton distribution in Icelandic waters in spring 1982, 1983 and 1984. Annales Biologiques 41, 63-66.

Vahl. O. 1980: Volume of water pumped and particulate matter deposited by the Iceland scallop Chlamys islandica in Balsfjord, northern Norway. Pp. 639-644 in Freeland, H. J., Farmer. D. M. \& Levings. C. D. (eds.): Fjord Oceanography. NATO Conf. Ser. (Ser. IV; Mar. Sci.). New York.

Wadhams, P. 1986: The ice cover. Pp. 21-84 in Hurdle, B. G (ed.): The Nordic Seas. Springer Verlag, Berlin.

Wassmann. P. 1983: Sedimentation of organic and inorganic particulate material in Lindåspollene, a stratified, land-locked fjord in western Norway. Mar. Ecol. Prog. Ser. 13, 237-248.

Wassmann, P. 1984: Sedimentation and benthic mineralization of organic detritus in a Norwegian fjord. Mar. Biol. 83, 83-94.

Wassmann. P. 1989: Sedimentation of organic matter and silicate from the euphotic zone of the Barents Sea. Rapp. P.-v. Réun. Cons. Int. Explor. Mer 188. 108-114.

Wassmann, P. 1990: Relationship between primary and export production in the boreal, coastal zone of the North Atlantic. Limnol. Oceanogr. 35, 464-471.

Wassmann, P., Vernet, M. Mitchell, G. \& Rey, F. 1990: Mass sedimentation of Phaeocystis pouchetii in the Barents Sea. Mar. Ecol. Prog. Ser. 66, 183-195.

Wassmann. P. 1991: Dynamics of primary production and sedimentation in shallow fjords and polls of western Norway. Oceanogr. Mar. Biol. Ann. Rev. 29.87-154.

Wiborg. K. F. 1955: Zooplankton in relation to hydrography in the Norwegian Sea. Fiskdir. Skr. Ser. Havunders. 11. 66 pp.

Zenkevitch. L. A. 1963: Biology of the seas of the USSR. George Allen \& Unwin Lid. London. 